\title{
Hypoxia-Inducible Factor $1 \alpha$ Signaling Promotes Repair of the Alveolar Epithelium after Acute Lung Injury
}

\author{
Jazalle McClendon, ${ }^{*}$ Nicole L. Jansing, ${ }^{*}$ Elizabeth F. Redente, ${ }^{\dagger \dagger}$ Aneta Gandjeva, ${ }^{\ddagger}$ Yoko Ito, ${ }^{*}$ Sean P. Colgan,,$\|$
} Aftab Ahmad, ${ }^{* *}$ David W.H. Riches, ${ }^{\dagger \ddagger}$ Harold A. Chapman, ${ }^{\dagger \dagger}$ Robert J. Mason, ${ }^{* \ddagger}$ Rubin M. Tuder, ${ }^{\ddagger \neq}$ and Rachel L. Zemans ${ }^{* \star}$

\begin{abstract}
From the Division of Pulmonary, Critical Care, and Sleep Medicine, ${ }^{*}$ Department of Medicine, and the Program in Cell Biology, ${ }^{\dagger}$ Department of Pediatrics, National Jewish Health, Denver, Colorado; the Division of Pulmonary Sciences and Critical Care Medicine, ${ }^{\ddagger}$ Mucosal Inflammation Program, ${ }^{\top}$ Integrated Department of Immunology, " and Program in Translational Lung Research, ${ }^{\ddagger \ddagger}$ Division of Pulmonary Sciences and Critical Care Medicine, University of Colorado Denver, Aurora, Colorado; the Department of Research,,$^{\S}$ Denver Veterans Affairs Medical Center, Denver, Colorado; the Department of Anesthesiology and Perioperative Medicine, ** University of Alabama at Birmingham, Birmingham, Alabama; and the Division of Pulmonary and Critical Care Medicine ${ }^{\dagger \dagger}$ University of California San Francisco, San Francisco, California
\end{abstract}

Accepted for publication April 20, 2017.

Address correspondence to Rachel L. Zemans, M.D., National Jewish Health, 1400 Jackson St., A547, Denver, CO 80206. E-mail: zemansr@ njhealth.org.

\begin{abstract}
During the acute respiratory distress syndrome, epithelial cells, primarily alveolar type (AT) I cells, die and slough off, resulting in enhanced permeability. ATII cells proliferate and spread onto the denuded basement membrane to reseal the barrier. Repair of the alveolar epithelium is critical for clinical recovery; however, mechanisms underlying ATII cell proliferation and spreading are not well understood. We hypothesized that hypoxia-inducible factor (HIF) $1 \alpha$ promotes proliferation and spreading of ATII cells during repair after lung injury. Mice were treated with lipopolysaccharide or hydrochloric acid. HIF activation in ATII cells after injury was demonstrated by increased luciferase activity in oxygen degradation domainLuc (HIF reporter) mice and expression of the HIF1 $\alpha$ target gene GLUT1. ATII cell proliferation during repair was attenuated in ATII cell-specific HIF1 $\alpha$ knockout $\left(S f t p c C r e E R T 2^{+/-} ; H I F 1 \alpha^{f / f}\right.$ ) mice. The HIF target vascular endothelial growth factor promoted ATII cell proliferation in vitro and after lung injury in vivo. In the scratch wound assay of cell spreading, HIF stabilization accelerated, whereas HIF1 $\alpha$ shRNA delayed wound closure. SDF1 and its receptor, CXCR4, were found to be HIF1 $\alpha$-regulated genes in ATII cells and were up-regulated during lung injury. Stromal cell-derived factor 1/CXCR4 inhibition impaired cell spreading and delayed the resolution of permeability after lung injury. We conclude that HIF1 $\alpha$ is activated in ATII cells after lung injury and promotes proliferation and spreading during repair. (Am J Pathol 2017, 187: 1772-1786; http://dx.doi.org/10.1016/j.ajpath.2017.04.012)
\end{abstract}

The alveolar epithelium is comprised of cuboidal alveolar type (AT)II cells and squamous ATI cells. ATI cells play a critical role in barrier function because they cover $98 \%$ of the alveolar surface and in gas exchange by virtue of their thin morphologic structure. In the acute respiratory distress syndrome (ARDS), alveolar epithelial cells, primarily ATI cells, die and slough off, leaving a denuded basement membrane and resulting in increased permeability, which in turn leads to the influx of edema fluid and refractory hypoxemia. ${ }^{1,2}$ The extent of epithelial injury determines the severity of ARDS, 3,4 and epithelial repair is critical for the resolution of edema and survival. ${ }^{5,6}$ ATII cells, which are relatively resistant to injury, reepithelialize the denuded alveolar surface by proliferating to replace lost cells and then spreading into cells that are morphologically intermediate between ATII and ATI cells and ultimately into squamous ATI cells (transdifferentiation). ${ }^{7-10}$ Although it has long been recognized

Supported by NIH grants HL103773 (R.L.Z.), HL124270 (R.L.Z.), HL131608 (R.L.Z.), and HL128484 (H.A.C.); the American Heart Association (R.L.Z.); the Boettcher Foundation (R.L.Z.); the Exxon Mobil Foundation (R.J.M.); and funds from the University of Colorado Denver Department of Medicine and National Jewish Health (R.L.Z.).

Disclosures: None declared.

Portions of data presented in this article were previously presented in abstract form at the Aspen Lung Conference, Aspen, CO, held June 4, 2014, and Experimental Biology, Boston, MA, held March 28 to April 1, 2015. 
that reepithelialization after lung injury depends on ATII cell proliferation and spreading, the molecular signaling pathways that promote these processes are not well understood. Hence, no specific therapies are currently available to enhance epithelial repair in ARDS, and management is mainly limited to supportive care. ${ }^{2}$

Here, we examined a potential role for hypoxia-inducible factor (HIF) in these processes. HIF signaling is known to be activated under inflammatory conditions. ${ }^{11}$ HIF promotes cell proliferation and motility during tumorigenesis and embryogenesis. ${ }^{12,13}$ In addition, HIF is strongly implicated in keratinocyte migration during wound repair, ${ }^{14,15}$ barrier protection in the gut, ${ }^{16,17}$ and tissue preservation after ischemic injury in multiple organs. ${ }^{18,19}$ HIF signaling is involved in alveolarization, ${ }^{20,21}$ can attenuate lung injury under some $\mathrm{e}^{22}$ but not all $^{23}$ circumstances, and has recently been suggested to be involved in ATII cell proliferation during the pathogenesis of pulmonary fibrosis. ${ }^{24}$ Vascular endothelial growth factor (VEGF) is an established HIF target gene that mediates the role of HIF in alveologenesis, angiogenesis, and tumorigenesis. ${ }^{13,21,25}$

The chemokine receptor CXCR4 and its ligand stromal cell-derived factor (SDF)1 (CXCL12) are known for their role in leukocyte migration, including homing to hematopoietic organs and recruitment to inflammatory foci. ${ }^{26,27}$ SDF1/CXCR4 signaling also induces cancer cell migration during metastasis ${ }^{28}$ and intestinal epithelial spreading and migration during barrier restitution. ${ }^{29}$ In addition, SDF1/ CXCR4 signaling can be activated during tissue injury, including in the lung, where it induces neutrophil and fibrocyte recruitment. ${ }^{30,31} C X C R 4^{32}$ and $S D F 1^{33}$ are both bona fide HIF1 target genes that partially mediate the role of HIF1 in cell motility.

On the basis of the potential roles for HIF signaling in cell proliferation and motility, as well as known activation of HIF in inflammatory foci, we hypothesized that HIF signaling may be activated and may promote ATII cell proliferation and spreading during repair after inflammatory injury in ARDS. We further hypothesized that VEGF and SDF1/CXCR4 signaling may mediate the role of HIF in ATII cell proliferation and spreading, respectively, during epithelial repair.

\section{Materials and Methods}

\section{Human Tissue}

Paraffin-embedded lung tissue from autopsy specimens of de-identified patients with diffuse alveolar damage and noninjured control lungs rejected for lung transplantation were obtained from the archives of University of Colorado Denver Department of Pathology. This tissue was deemed exempt from the requirement for informed consent by the Colorado Multiple Institutions Review Board.

\section{Animal Studies}

All animal protocols were approved by the Animal Care and Use Committee at National Jewish Health. Mice and rats were maintained in a pathogen-free environment on a 12-hour light/ dark cycle with full access to food and water. SftpcCreERT2 mice $^{34}$ were crossed to HIFl $\alpha^{f f f}$ or Rosa26-mTmG (abbreviated $\mathrm{mTmG}$ ) mice (The Jackson Laboratories, Bar Harbor, ME). Genotyping was performed by nonquantitative PCR on gDNA isolated from tail clips using the primer sequences listed in Table 1. SftpcCreERT2 ${ }^{+/}$;HIFI $\alpha^{\text {fff }}$ or SftpcCreERT2 ${ }^{+/-}$; $m T m G^{+/-}$mice were administered tamoxifen, starting at 4 weeks of age. Mice were fed tamoxifen citrate $400 \mathrm{mg} / \mathrm{kg}$ chow (Harlan, Indianapolis, IN) for 2 weeks or treated with tamoxifen $20 \mathrm{mg} / \mathrm{mL}$ in corn oil at a dose of $0.25 \mathrm{mg} / \mathrm{g}$ of body weight i.p. every other day for three doses. Tamoxifen administration was followed by a washout period of 4 weeks. Lungs of naive SftpcCreERT2 ${ }^{+/-} ; H I F 1 \alpha^{f f f}$ mice or littermate controls lacking one of the transgenes were digested as previously described. ${ }^{35}$ Briefly, after euthanasia, the chest was opened, and lungs were perfused with $10 \mathrm{~mL}$ of phosphate-buffered saline through the right ventricle. Lungs were instilled with $3 \mathrm{~mL}$ of dispase (Corning, Corning, NY), followed immediately by $0.5 \mathrm{~mL}$ of low melting point agarose. Ice was placed on the lungs for 2 minutes. Lungs were removed and incubated in $1 \mathrm{~mL}$ of dispase at $37^{\circ} \mathrm{C}$ for 7 minutes. Five milliliter Dulbecco's modified Eagle's medium (DMEM) and $120 \mathrm{U} / \mathrm{mL}$ DNase were added, and lungs were minced for 8 seconds on a gentleMACS Dissociator (Miltenyi Biotec, Bergisch Gladbac, Germany). Cell suspension was filtered through 100-, 40-, and 20- $\mu \mathrm{m}$ strainers. Cells were

Table 1 Primer Sequences

\begin{tabular}{|c|c|c|}
\hline Gene name & Forward & Reverse \\
\hline Cre & 5'-ATGTCCAАTTTACTGACCG-3' & 5'-CGCGCCTGAAGATATAGAAG-3' \\
\hline Hif1 $\alpha$ Flox & $5^{\prime}$-GCAGTTAAGAGCACTAGTTG-3' & 5'-GGAGCTATCTCTCTAGACC-3' \\
\hline $\mathrm{mCx}$ Cr4 & 5'-TCCAGACCCСАСТTСТTCAG-3' & 5'-AGTGACCCTCTGAGGCGTTT-3' \\
\hline mGlut1 & $5^{\prime}$-GAGACCAAAGCGTGGTGAGT-3' & 5'-GCAGTTCGGCTATAACACTGG-3' \\
\hline mVegfa & $5^{\prime}-\mathrm{TGCGGATCAAACCTCACCAA-3^{ \prime }}$ & $5^{\prime}$-GGTCTGCАTTCAСАТСTGCTG-3' \\
\hline rVegfa & $5^{\prime}$-CTGGACCCTGGCTTTACTGC-3' & 5'-АСТTСАССАСТTСАTGGGCTT-3' \\
\hline $\mathrm{rCxcr} 4$ & $5^{\prime}$-GCCATGGAAATATACACTTCGGA-3' & 5'-TTTTCATCCCGGAAGCAGGG-3' \\
\hline
\end{tabular}


stained with anti-epithelial cell adhesion molecule (EpCAM)647 (catalog number 118212; BioLegend, San Diego, CA) and anti-CD45-BV510 (catalog number 103138; BioLegend). The $\mathrm{EpCAM}^{+}, \mathrm{CD}^{-} 5^{-}$population was purified using a MoFlo (Beckman Coulter, Brea, CA) cell sorter, which yields approximately $90 \%$ ATII cells, as determined by immunofluorescent staining of cytospins for prosurfactant protein $\mathrm{C}$ (proSPC; catalog number AB3786; Millipore, Billerica, MA) (data not shown). gDNA was isolated from ATII cells, and PCR was performed by GeneTyper Mouse Genotyping Services (New York, NY) using primers that flank exon 2. Deletion of exon 2 results in a 300-bp product; intact exon 2 results in a predicted 820-bp product, which is often too large to amplify. SftpcCreERT2 ${ }^{+/} ; m T m G^{+/-}$, C57BL/6 (Charles River Laboratories/NCI, Wilmington, MA), FVB.129S6-Gt(Rosa) 26 Sor $^{\text {tm2(HIFIA/luc)Kael }}$ [oxygen degradation domain (ODD)Luc; The Jackson Laboratories], or female SftpcCreERT2 ${ }^{+/}$; $H I F 1 \alpha^{f f f}$ mice (or littermate controls lacking one of the transgenes), aged 8 to 12 weeks, were treated with $2 \mu \mathrm{g} / \mathrm{g}$ body weight lipopolysaccharide (LPS) (Escherichia coli 0111:B4; List Biological Laboratories, Campbell, CA) or $2 \mu \mathrm{L} / \mathrm{g}$ body weight hydrochloric acid $(\mathrm{HCl}) 0.075 \mathrm{~N}, \mathrm{pH} 1.18$, in $50 \mu \mathrm{L}$ of saline by i.t. instillation and euthanized at various time points. In indicated experiments, C57BL/6 mice were administered AMD3100 (catalog number 5602; Sigma-Aldrich, St. Louis, MO) $200 \mu \mathrm{g}$ or SU5416 (catalog number 13342; Cayman Chemical, Ann Arbor, MI) $20 \mathrm{mg} / \mathrm{kg}$ of body weight in $500 \mu \mathrm{L}$ of phosphate-buffered saline by i.p. injection daily, beginning at day 3 after i.t. LPS. In indicated experiments, mice were treated with $1 \mathrm{mg}$ of bromodeoxyuridine (BrdU; catalog number 557892; Becton Dickinson, Franklin Lakes, NJ) or $0.5 \mathrm{mg}$ of 5ethynyl-2'-deoxyuridine (catalog number C10340; Thermo Scientific, Waltham, MA) in 100 to $200 \mu \mathrm{L}$ of phosphatebuffered saline i.p. 24 hours before euthanasia. Bronchoalveolar lavage (BAL) was performed using three $0.8-\mathrm{mL}$ lavages. Cell counts and albumin enzyme-linked immunosorbent assay (Bethyl Laboratories, Montgomery, TX) were performed on BAL fluid. In indicated experiments, $400 \mu \mathrm{L}$ of BAL fluid was ultracentrifuged at $100,000 \times g$ for 2 hours, the pellet was lyzed in $25 \mathrm{mmol} / \mathrm{L}$ Tris, $10 \%$ glycerol, $1 \%$ IGEPAL, $\mathrm{pH} 7.5$, supplemented with Complete Mini Protease Inhibitor Cocktail (Roche, Indianapolis, IN), and subjected to Western blot analysis for T1 $\alpha$ (catalog number 11936; Abcam, Cambridge, UK). Lungs were inflation-fixed at $25 \mathrm{~cm}$ of $\mathrm{H}_{2} \mathrm{O}$ pressure with $10 \%$ phosphate-buffered formalin, embedded in paraffin, and cut into $4-\mu \mathrm{m}$ sections, or lungs were digested as described above. In indicated experiments, lungs were frozen in liquid nitrogen, and RNA was isolated using the mirVana Isolation Kit (Invitrogen, Carlsbad, CA) or luciferase activity was measured using the Luciferase Assay System (Promega, Madison, WI) on a Synergy Mx microplate reader (BioTek, Winooski, VT).

\section{Immunostaining}

Lung sections were deparaffinized in xylene, hydrated with graded ethanol solutions, and equilibrated to water. When indicated, hematoxylin and eosin staining was performed. For immunostaining, antigen retrieval was performed by boiling slides in Target Retrieval Solution (Dako, Santa Clara, CA) for 30 to 50 minutes. Sections were then blocked in 5\% goat serum in Tris-buffered saline with $0.05 \%$ Tween, followed by incubation with anti-glucose transporter 1 (GLUT1; catalog number 40084; Abcam), anti-SDF1 (catalog number MAB350; R\&D Systems, Minneapolis, MN), anti-VEGFA (catalog number 52917; Abcam), and/or anti-proSPC (catalog number AB3786; Millipore, Billerica, MA) antibody, and then Alexa 488- or 555- or 647conjugated anti-mouse or anti-rabbit secondary antibodies (Invitrogen). Slides were mounted with Vectashield HardSet mounting medium with DAPI (Vector Laboratories, Burlingame, CA). Digital images were acquired using a Zeiss Axiovert 200 microscope. Costaining of GLUT1 and proSPC was determined by Pearson's Correlation Coefficient $^{36}$ using ZEN 2012 colocalization software (Zeiss, Jena, Germany). Total fluorescence intensity of SDF1 or VEGF per high power field was quantified by ImageJ software version 1.48 (NIH, Bethesda, MD; http://imagej.nih.gov/ij).

\section{Flow Cytometry of Lung Cells}

After lung digest as described above, cells were stained with anti-EpCAM-647 (catalog number 118212; BioLegend) or -fluorescein isothiocyanate (catalog number 118207; BioLegend), anti-CD45-BV510 (catalog number 103138; BioLegend), -peridinin-chlorophyll protein and cyanine 5.5 (catalog number 45-0451; eBioscience, San Diego, CA), or -A700 (catalog number 56-0451-82; eBioscience), anti-BrdU647 (catalog number 557892; Becton Dickinson), anti-5ethynyl-2'-deoxyuridine-647 (catalog number C10340; Thermo Scientific), anti-Ki-67-660 (catalog number 50-5698; eBioscience) or -fluorescein isothiocyanate (catalog number 11-5698; eBioscience), and/or unconjugated anti-GLUT1 (catalog number 40084; Abcam) or anti-proSPC (catalog number AB3786; Millipore), followed by anti-mouse-647 secondary (Invitrogen) antibodies and analyzed on the LSRFortessa X-20 cytometer (BD Biosciences, San Jose, CA).

\section{Cell Culture}

MLE-12 cells (ATCC, Manassas, VA) were grown in DMEM (Invitrogen) containing $44 \mathrm{mmol} / \mathrm{L} \mathrm{NaHCO}_{3}, 1 \mathrm{mmol} / \mathrm{L}$ sodium pyruvate, $4 \mathrm{mmol} / \mathrm{L}$ L-alanyl-glutamine, $90 \mu \mathrm{g} / \mathrm{mL}$ streptomycin, $40 \mu \mathrm{g} / \mathrm{mL}$ penicillin, and $10 \%$ fetal bovine serum (FBS; Hyclone, San Angelo, TX) or DMEM:F12 containing $0.005 \mathrm{mg} / \mathrm{mL}$ insulin, $0.01 \mathrm{mg} / \mathrm{mL}$ transferrin, 30 $\mathrm{nmol} / \mathrm{L}$ sodium selenite, $10 \mathrm{nmol} / \mathrm{L}$ hydrocortisone, $10 \mathrm{nmol} /$ $\mathrm{L} \beta$-estradiol, $10 \mathrm{mmol} / \mathrm{L}$ HEPES, $2 \mathrm{mmol} / \mathrm{L}$ L-glutamine, 90 $\mu \mathrm{g} / \mathrm{mL}$ streptomycin, $40 \mu \mathrm{g} / \mathrm{mL}$ penicillin, and $2 \%$ FBS. ATII cells were isolated from male Sprague-Dawley rats weighing 175 to $199 \mathrm{~g}$ (Charles River Laboratories) as previously described. ${ }^{37}$ Freshly isolated or frozen cells were plated on tissue culture plastic in DMEM with 10\% FBS or on Millicell 
transwell inserts (Millipore) coated with 20\% Matrigel (BD Biosciences) and $80 \%$ rat tail collagen in DMEM with 5\% rat serum (Pel-Freez Biologicals, Rogers, AR) and $10 \mathrm{ng} / \mathrm{mL}$ keratinocyte growth factor (Amgen, Thousand Oaks, CA) in air-liquid interface. Media were changed on day 1 and then every other day thereafter.

\section{In Vitro Proliferation}

MLE-12 cells $\left(0.4 \times 10^{6}\right.$ per well $)$ were plated in a 24 -well plate. The next day, cells were treated with $5 \mu \mathrm{g} / \mathrm{mL}$ mitomycin for 24 hours, then trypsinized and counted. Rat ATII cells were grown to confluence, subjected to scratch wounding, and then cultured in $1 \%$ charcoal stripped FBS with 1 $\mu \mathrm{mol} / \mathrm{L}$ BrdU. In indicated experiments, rat ATII cells $(1 \times$ $10^{6}$ per well) were plated in a 12 -well plate and cultured in $1 \%$ charcoal stripped FBS with $1 \mu \mathrm{mol} / \mathrm{L} \mathrm{BrdU}$ in the presence or absence of $10 \mathrm{ng} / \mathrm{mL}$ recombinant (r) human keratinocyte growth factor (Amgen) or $20 \mathrm{ng} / \mathrm{mL}$ recombinant murine (rm) VEGF (PeproTech); alternatively, rat ATII cells were cultured in $10 \% \mathrm{FBS}$ with $1 \mu \mathrm{mol} / \mathrm{L} \mathrm{BrdU}$ in the presence or absence of SU5416 or dimethyl sulfoxide as a control. After 24 hours, cells were trypsinized, counted, stained with anti-BrdU antibody (catalog number 557892; Becton Dickinson), and analyzed on an LSR II flow cytometer (BD Biosciences).

\section{Transfection}

MLE-12 cells were grown to $70 \%$ to $80 \%$ confluence and transfected with a hypoxia response element (HRE) Firefly luciferase reporter plasmid ${ }^{38}$ and a Renilla luciferase reporter plasmid (Promega) using Lipofectamine 2000 (Life Technologies, Carlsbad, CA) according to the manufacturer's instructions. Briefly, $0.4 \times 10^{6}$ cells were cultured per well in a 12-well plate. The next day, $1.6 \mu \mathrm{g}$ of HRE plasmid and 100 ng of Renilla plasmid with $4 \mu \mathrm{L}$ of Lipofectamine was incubated for 20 minutes and then added to each well and incubated for 18 hours. Cells were lyzed in Passive Lysis Buffer (Promega), and Renilla and Firefly luciferase activity were determined using the Luciferase Assay System (Promega) on a Synergy Mx microplate reader (BioTek).

\section{Lentiviral Transduction}

MLE-12 cells were grown to $30 \%$ confluence in a 24 -well tissue culture plate, then incubated with $400 \mu \mathrm{L}$ of lentivirus containing shRNA to HIF1 $\alpha$ (catalog number 0000232223; TRC, Cambridge, MA) or a nonsilencing shRNA (SHC216) (Functional Genomics Facility, University of Colorado, Boulder, CA) and $8 \mu \mathrm{g} / \mathrm{mL}$ polybrene for 16 hours. At 48 hours after transduction, cells were cultured in media with puromycin $4 \mu \mathrm{g} / \mathrm{mL}$ for at least 72 hours.

\section{Adenoviral Transduction}

Freshly isolated rat ATII cells were transduced with adenovirus expressing green fluorescent protein (GFP;
AdGFP), LacZ (AdLacZ), or a constitutively active mutant $H I F 1 \alpha$ construct $\left(\mathrm{AdHIFI} \alpha^{39}\right)$ at multiplicity of infection 20 in DMEM with $2 \% \mathrm{FBS}$ at $37^{\circ} \mathrm{C}$ with gentle rocking for 3 hours and then plated on $80 \%$ rat tail collagen/20\% Matrigel in DMEM with 5\% rat serum. RNA was harvested 24 hours later.

\section{qPCR/Microarray}

Cells were lyzed in Buffer RLT (Qiagen, Hilden, Germany), and RNA was purified using the RNeasy Mini QIAcube Kit on a QIAcube (Qiagen) according to the manufacturer's instructions. RNA was reverse transcribed into cDNA using the QuantiTect Kit (Qiagen) according to the manufacturer's instructions. cDNA was analyzed by real-time quantitative PCR (qPCR) using primers for GLUT1,VEGF, SDF1, and CXCR4 (Table 1). qPCR was performed for 40 cycles on the CFX96 (Bio-Rad, Hercules, CA) using iQ SYBR Green Supermix (Bio-Rad). Relative mRNA expression levels were calculated using the $2^{-\Delta \Delta \mathrm{Ct}}$ method. ${ }^{40}$ In indicated experiments, cDNA was subjected to a GeneChip Rat Gene 2.0 ST array (Affymetrix, Santa Clara, CA).

\section{Immunoblotting}

Cells were lysed in $25 \mathrm{mmol} / \mathrm{L}$ Tris, $10 \%$ glycerol, $1 \%$ IGEPAL, pH 7.5, supplemented with Complete Mini Protease Inhibitor Cocktail (Roche). Nuclear extracts were prepared using the NE-PER Nuclear Protein Extraction Kit (Pierce, Waltham, MA) according to the manufacturer's instructions. Whole cell lysates or nuclear extracts were analyzed by SDSPAGE and immunoblotting for HIF $1 \alpha$ (catalog number 100134; Novus Biologicals, Littleton, CO), CXCR4 (catalog number 13854; Abcam), TATABox Binding Protein (catalog number 818; Abcam), or actin (catalog number 3280; Abcam). Densitometry was performed using ImageJ software (NIH).

\section{Scratch Wounding}

Rat ATII cells or MLE-12 cells \pm HIF1 $\alpha$ shRNA were grown to confluence on tissue culture plastic and subjected to scratch wounding with a pipette tip. Immediately after the wound was made, cells were treated with 0.5 to $1 \mathrm{mmol} / \mathrm{L}$ dimethyloxalylglycine (DMOG; Cayman Chemical) or $500 \mathrm{ng} / \mathrm{mL}$ rmSDF1 (PeproTech) or $1 \mu \mathrm{g} / \mathrm{mL}$ mitomycin or $0.1 \mu \mathrm{g} / \mathrm{mL}$ cytochalasin D or $5 \mu \mathrm{g} / \mathrm{mL}$ AMD3100, or 100 to $200 \mu \mathrm{mol} / \mathrm{L}$ blebbistatin (catalog number 203389; Millipore) or $50 \mu \mathrm{mol} / \mathrm{L} \mathrm{NSC23766} \mathrm{(Tocris} \mathrm{Bioscience,} \mathrm{Bristol,}$ UK) or dimethyl sulfoxide as a control in DMEM with $1 \%$ to $10 \%$ FBS. Images were obtained on an Olympus (Tokyo, Japan) DC70 microscope immediately after the wound was made and 24 hours later. Wound width was calculated using ImageJ software (NIH), and wound repair was expressed as the percentage of initial wound remaining at 24 hours. In indicated experiments, images were also captured $>1 \mathrm{~mm}$ away from the wound. 


\section{Hypoxia/DMOG Exposure}

Cells were exposed to hypoxia $\left(1 \% \mathrm{O}_{2}, 5 \% \mathrm{CO}_{2}, 94 \% \mathrm{~N}_{2}\right)$ or normoxia $\left(21 \% \mathrm{O}_{2}, 5 \% \mathrm{CO}_{2}, 74 \% \mathrm{~N}_{2}\right)$ in a Modular Incubator Chamber (Billups-Rothenberg, Inc., San Diego, CA) or treated with DMOG 0.5 to $1 \mathrm{mmol} / \mathrm{L}$ for 16 to 48 hours.

\section{Phalloidin Staining}

Cultured cells were fixed in $3 \%$ paraformaldehyde, permeabilized in $0.2 \%$ Triton $\mathrm{X}-100$, blocked in $1 \%$ bovine serum albumin, and stained with phalloidin-Alexa 594 (Invitrogen) for 25 minutes.

\section{Statistical Analysis}

Data are expressed as means \pm SEM. Statistical analysis was performed by paired or unpaired $t$-test. Multiple comparisons were performed by one-way analysis of variance with post hoc Bonferroni's multiple comparison test. $P<0.05$ was considered significant. GraphPad Prism software version 5.04 (GraphPad Inc., San Diego, CA) was used for all statistical calculations. In vivo data were analyzed from $\geq 2$ independent experiments with $\geq 5$ mice/ group. In vitro data were analyzed from $\geq 3$ independent experiments each performed in duplicate or triplicate.

\section{Results}

\section{HIF Is Activated in ATII Cells in Lung Injury}

LPS and $\mathrm{HCl}$, models of infection and aspiration, respectively, both caused injury to the alveolar epithelium, including death and sloughing of ATI cells, as measured by detection of the ATI cell marker T1 $\alpha$ in the BAL sediment (Supplemental Figure S1A), which has previously been shown to correlate with loss of ATI cells by electron microscopy. ${ }^{41}$ This injury was accompanied by epithelial permeability and inflammation, as measured by increased BAL albumin and inflammatory cell accumulation, respectively (Figure 1A and Supplemental Figure S1B). Injury peaked at day 3.

To determine whether HIF signaling was activated in mouse models of lung injury, we used a bioluminescent HIF1 $\alpha$ reporter mouse, ODD-Luc. These mice expressed the ODD of HIFl $\alpha$ fused to firefly luciferase. Because hydroxylation of the ODD targeted HIF1 $\alpha$ or the luciferase fusion protein for ubiquitination and proteosomal degradation, detectable luciferase activity reflected HIF1 $\alpha$ stabilization. ${ }^{42}$ In the naive lung, some luciferase activity was detectable (Figure 1B), likely reflecting the presence of low levels of HIF $1 \alpha$, which is known to be constitutively synthesized and rapidly degraded under normoxic conditions. ${ }^{12}$ However, luciferase activity in the whole lung homogenate markedly increased after lung injury induced by LPS or $\mathrm{HCl}$ (Figure 1B and Supplemental Figure S2A). To confirm that HIF signaling was activated in ATII cells after lung injury, we assessed ATII cell expression of GLUT1, a prototypical HIF1 target gene. ${ }^{43}$ SftpcCreERT2 ${ }^{+/-} ; m T m G^{+/-}$mice, in which ATII cells are induced by tamoxifen to express GFP, were treated with LPS or saline as a control. We confirmed that the $\mathrm{GFP}^{+}$cells were indeed ATII cells, as demonstrated by expression of the ATII cell marker proSPC (Supplemental Figure S2B). Moreover, GLUT1 expression by ATII cells was up-regulated after lung injury induced by LPS (Figure 1C and Supplemental Figure S2C). Increased expression of GLUT1 in ATII cells was confirmed by costaining lung sections from LPS- and HCl-treated mice for GLUT1 and proSPC (Supplemental Figure S2D). Finally, we detected increased levels of VEGF, another established HIF1 target gene, ${ }^{13}$ in the lung after injury (Figure 1D and Supplemental Figure S2E).

\section{HIF Promotes Epithelial Repair}

A critical stage of repair after epithelial injury in human ARDS patients was ATII cell proliferation ${ }^{7,8}$ (Supplemental Figure S3).
A

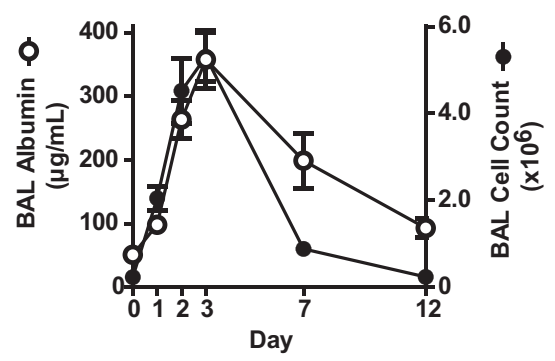

B

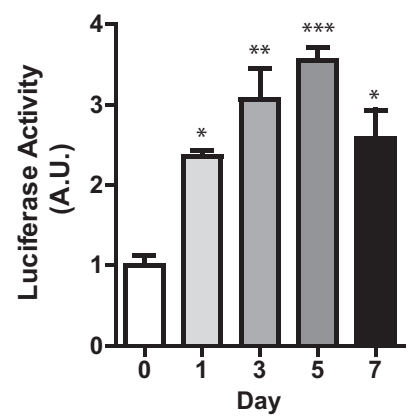

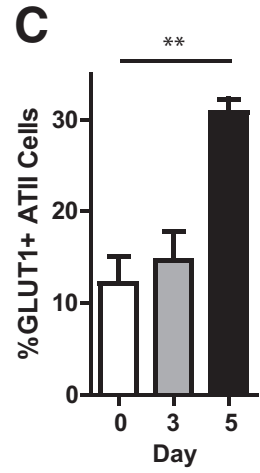

Figure 1 HIF signaling is activated in mouse models of lung injury. A-D: C57BL/6 (A and D) or ODD-Luc (B) or SftpcCreERT2 $2^{+/-} ; m T m G^{+/-}$(C) mice were treated with i.t. LPS and euthanized at the indicated time points. A: Cell counts and albumin were measured in the bronchoalveolar lavage (BAL). B: Luciferase

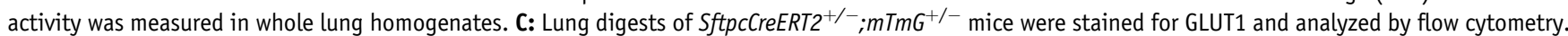
GLUT1 expression in the GFP ${ }^{+}$(ATII cell) population is shown. D: Lung sections were stained for VEGF and intensity of staining was quantified by ImageJ software version 1.48 (NIH, Bethesda, MD; http://imagej.nih.gov/ij) analysis. Data are expressed as means \pm SEM $(\mathbf{B}-\mathbf{D}) .{ }^{*} P<0.05,{ }^{* *} P<0.01$, and ${ }^{* * * P}<0.001$. ATII, alveolar type II; A.U., arbitrary unit; BAL, bronchoalveolar lavage; GFP, green fluorescent protein; GLUT1, glucose transporter 1; HIF, hypoxia-inducible factor; LPS, lipopolysaccharide; ODD, oxygen degradation domain; VEGF, vascular endothelial growth factor. 
To determine the role of HIF1 in ATII cell proliferation after lung injury in animal models, we generated ATII cell-specific, inducible $H I F l \alpha$ knockout mice by crossing SftpcCreERT2 mice to HIFl $\alpha^{f / f}$ mice. Deletion of the HIFl $\alpha$ gene from ATII cells was confirmed by PCR using primers designed to detect the null allele performed on genomic DNA extracted from freshly isolated ATII cells (Supplemental Figure S4A). At baseline, SftpcCreERT2 ${ }^{+/}$;HIFl $\alpha^{\text {fff }}$ mice treated with tamoxifen displayed no abnormalities in alveolar structure or barrier integrity and no inflammation (Supplemental Figure S4, B and C). Moreover, no significant difference was found in the initial injury induced by LPS or $\mathrm{HCl}$, as assessed by inflammation and permeability on day 3 (Supplemental Figure S4, D and E), which was the peak of injury (Figure 1A and Supplemental Figure S1B). To assess the role of HIF1 $\alpha$ in ATII cell proliferation during repair after lung injury, we first determined the time course of ATII cell proliferation after LPS (Figure 2A and Supplemental Figure S5) and found that ATII cell proliferation was temporally correlated with HIF activation (Figure 1). Importantly, in the ATII cell-specific HIFl $\alpha$ knockout (KO) $\left(\right.$ SftpcCreERT2 $\left.{ }^{+/-} ; H I F 1 \alpha^{f f f}\right)$ animals, there was attenuated proliferation at the peak of the proliferative response on day 5 (Figure 2B). (After HCl-induced injury, the KO mice had a 38\% mortality rate, compared with a $17 \%$ mortality rate in the wildtype animals, with animal death occurring between day 4 and day 7. This was thought to be too high to be conducive to further study.) Because HIF is a transcription factor, we questioned whether the prototypical HIF target gene VEGF may be a potential mediator of the role of HIF1 $\alpha$ in ATII cell proliferation. Accordingly, freshly isolated rat ATII cells were cultured in the presence of rVEGF or SU5416, a VEGF receptor antagonist. Entry of cells into $S$ phase of the cell cycle and cell division were determined by BrdU uptake and total cell number, respectively. rVEGF enhanced (Figure 2C), whereas SU5416 prevented (Figure 2D) ATII cell proliferation. Notably, the cells treated with SU5416 were deemed viable by trypan blue staining (data not shown) and appeared healthy (Supplemental Figure S6). To confirm that VEGF was critical for ATII cell proliferation during repair after lung injury, LPS-treated mice were administered SU5416 daily, beginning at day 3 after LPS, after injury was established. VEGF receptor blockade attenuated ATII cell proliferation during repair (Figure 2E).

To determine whether HIF1 $\alpha$ also promoted ATII cell spreading during epithelial repair, we used the in vitro scratch wound assay, which has been previously suggested to be an assay of cell spreading. ${ }^{44,45}$ We confirmed that scratch wounds in cultured primary ATII cells and MLE-12 cells, a cell line that has properties of ATII cells such as SPC expression, ${ }^{46}$ closed by cell spreading/migration and did not require cell replication. Mitomycin blocked proliferation (Figure 3A) but did not delay wound closure (Figure 3B) in a wounded monolayer of MLE-12 cells. In contrast, treatment with cytochalasin $\mathrm{D}$, which inhibited actin polymerization and cytoskeletal reorganization, prevented wound closure (Figure 3C). Primary ATII cells proliferated minimally under the low serum conditions in which they are cultured during the 24-hour period of wound closure, and there was no increased proliferation in response to scratch wounding (Figure 3D). Instead, the cells that have reepithelialized the wound displayed a spread morphologic structure (Figure 3E and Supplemental Figure S7). Thus, scratch wounds in this system closed by ATII cell spreading.

To determine whether HIF signaling promoted ATII cell spreading, we used shRNA to knockdown HIF1 $\alpha$ in MLE-12 cells. This yielded $60 \% \pm 18 \%$ knockdown (Figure 4A) and inhibited up-regulation of the prototypical HIF target genes $V E G F$ and GLUT1 in response to the HIF stabilizer (prolyl hydroxylase inhibitor) DMOG (Figure 4B). HIF1 $\alpha$ knockdown delayed wound closure (Figure 4C). To confirm these findings in primary cells, a rat ATII cell monolayer was subjected to scratch wounding, followed by treatment with DMOG, which also effectively induced expression of VEGF and GLUT1 in these cells (Figure 4D). HIF activation by DMOG accelerated wound closure in rat ATII cells (Figure 4E). Similarly, in MLE-12 cells, DMOG, which stabilized HIF1 $\alpha$ (Figure 4F) and increased HIF transcriptional activity (Figure 4, G and $\mathrm{H}$ ), accelerated wound closure (Figure 4I). Because in vitro epithelial scratch wounds were repaired by cell spreading (Figure 3 and Supplemental Figure S7) and HIF1 $\alpha$ promoted wound closure (Figure 4), we concluded that HIF1 $\alpha$ promoted ATII cell spreading.

\section{HIF1 Induces CXCR4 and SDF1 Expression in ATII Cells}

To identify HIF $1 \alpha$-dependent genes that might mediate the role of HIF $1 \alpha$ in ATII cell spreading and migration during repair, we performed a genome-wide microarray on rat ATII cells transduced with an adenovirus containing a constitutively active mutant HIFl $\alpha$ construct (AdHIFl $\alpha$ ). We observed up-regulation of established HIF target genes, including those involved in oxygen supply (HMOX1), glycolysis (phosphofructokinase, aldolase C, phosphoglycerate kinase, phosphoglucomutase, enolase, $P F K F B 3)$, glucose transport (GLUT1), $\mathrm{pH}$ regulation (CAIX, XII), and growth (VEGF, IGFBP2) (Figure 5A). Complete results of the array are available at Gene Expression Omnibus (https://www.ncbi.nlm.nih.gov/geo; accession number GSE87555). Up-regulation of several of these genes in response to adenoviral-mediated HIF1 $\alpha$ expression was confirmed by qPCR (Supplemental Figure S8). Of the genes that were up-regulated in response to HIF1 $\alpha$ overexpression, CXCR4 and its ligand SDF1 (Figure 5A) have been previously implicated in cell motility. ${ }^{26,29-31,33}$ Accordingly, we confirmed that CXCR4 and SDF1 were up-regulated by HIF1 $\alpha$ expression in rat ATII cells by qPCR (Figure 5B); in fact, the fold change up-regulation for both genes was much greater by qPCR than by the hybridization array. HIF stabilization via DMOG also induced CXCR4 and SDF1 expression in rat ATII cells (Figure 5C). CXCR4 mRNA and protein expression were also increased in MLE-12 cells in response to stimulation with DMOG or exposure 


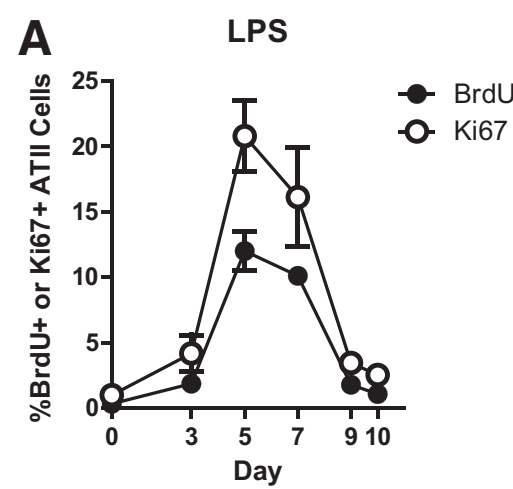

C
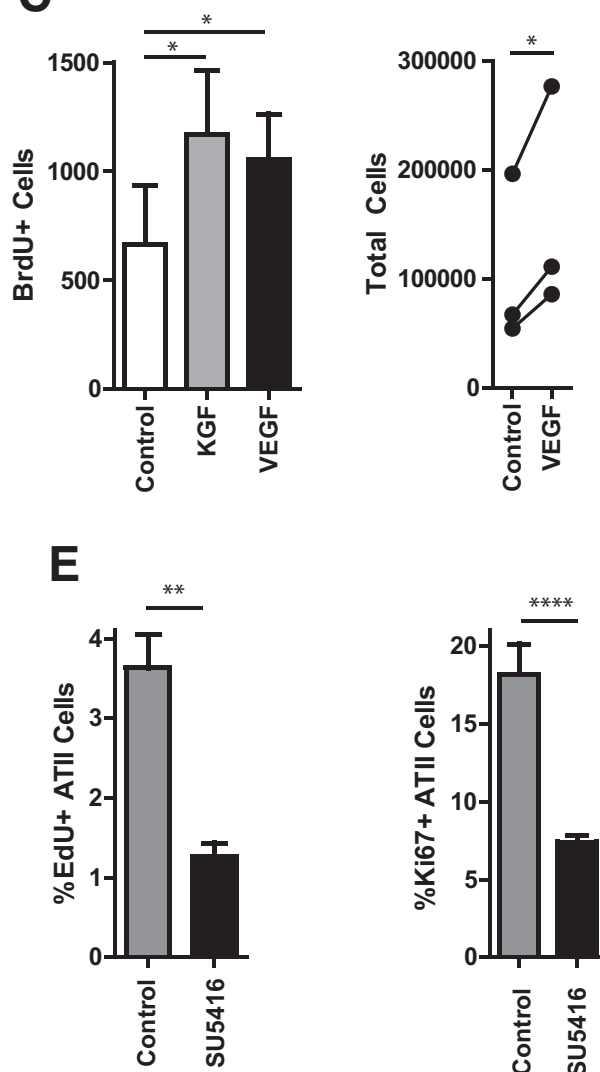

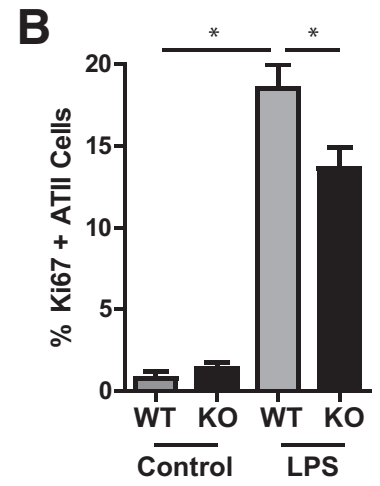

D
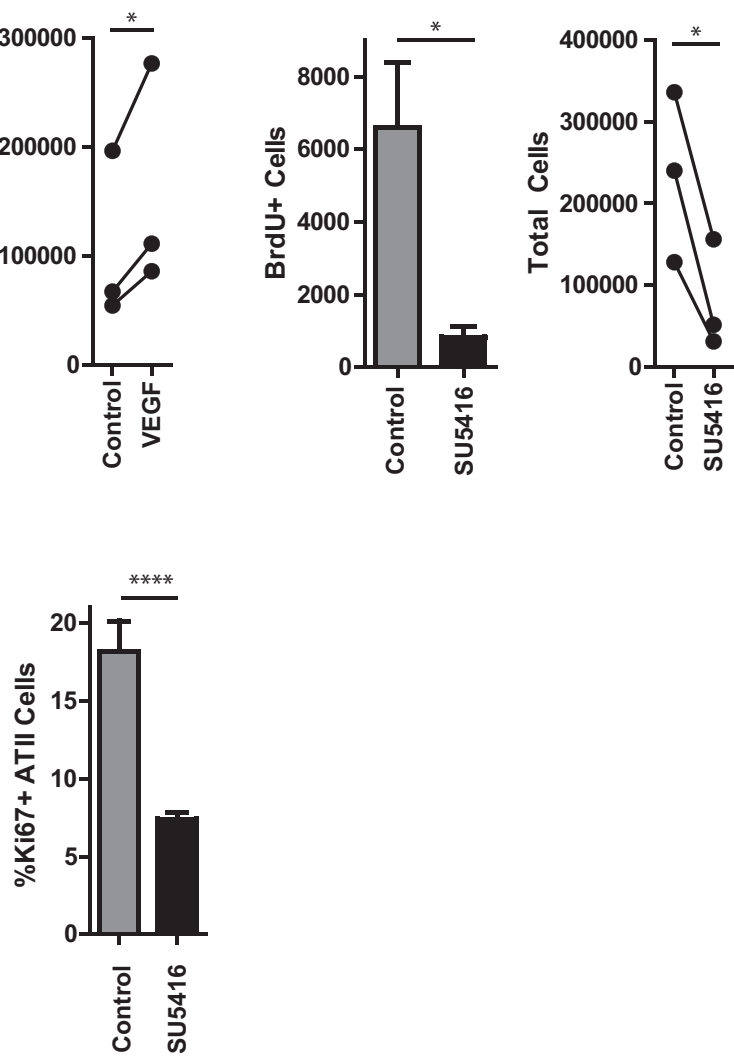

Figure 2 HIF promotes ATII cell proliferation during epithelial repair. A: SftpcCreERT2 ${ }^{+/-} ; \mathrm{mTmG}^{+/-}$ mice were treated with i.t. LPS, followed by i.p. BrdU 24 hours before euthanasia. Mice were euthanized at the indicated time points, and lungs were digested, stained for BrdU and Ki-67, and analyzed by flow cytometry. BrdU/Ki-67 expression in the GFP+ (ATII cell) population is shown. B: WT or ATII cell-specific HIF1 $\alpha$ K0 (SftpcCreERT2 ${ }^{+-} ;$HIF1 $\alpha^{f / f}$ ) mice were treated with i.t. LPS and euthanized 5 days later. Lungs were digested, stained for EpCAM, proSPC, CD45, and Ki-67. Ki-67 expression in the CD $45^{-}$EpCAM $^{+}$proSPC $^{+}$ (ATII cell) population is shown. C: Rat ATII cells were cultured in DMEM with $1 \%$ charcoal stripped FBS in the presence of $10 \mathrm{ng} / \mathrm{mL} \mathrm{KGF}$ or $20 \mathrm{ng} / \mathrm{mL}$ VEGF and BrdU. D: Rat ATII cells were cultured in DMEM with $10 \%$ FBS in the presence of $20 \mu \mathrm{mol} / \mathrm{L} \mathrm{SU} 5416$ and BrdU. C and D: At day 3, cells were trypsinized, counted, stained with anti-BrdU antibody, and analyzed by flow cytometry. Total cell numbers were normalized to the control value for each experiment for statistical analysis. E: SftpcCreERT2 ${ }^{+/-} ; m \mathrm{TmG}^{+/-}$mice were treated with LPS, followed by daily i.p. administration of SU5416, beginning at day 3, and i.p. EdU 24 hours before euthanasia. Mice were euthanized at day 5 , and lungs were digested, stained for EdU and Ki-67, and analyzed by flow cytometry. EdU/Ki-67 expression in the $\mathrm{GFP}^{+}$(ATII cell) population are shown. Data are expressed as means \pm SEM (B-E). ${ }^{*} P<0.05$, $* * P<0.01$, and ${ }^{* * * *} P<0.0001$. ATII, alveolar type II; BrdU, bromodeoxyuridine; DMEM, Dulbecco's modified Eagle's medium; EdU, 5-ethynyl-2'-deoxyuridine; EpCAM, epithelial cell adhesion molecule; FBS, fetal bovine serum; GFP, green fluorescent protein; HIF, hypoxia-inducible factor; KGF, keratinocyte growth factor; KO, knockout; LPS, lipopolysaccharide; proSCP, prosurfactant protein C; VEGF, vascular endothelial growth factor; WT, wild-type. to hypoxia, and this was prevented by HIF1 $\alpha$ shRNA knockdown (Figure 5, D and E).

\section{CXCR4/SDF1 Signaling Promotes ATII Cell Spreading}

Given that HIF1 $\alpha$ promotes ATII cell spreading during epithelial repair (Figure 4) and that CXCR4 and SDF1 are HIF1 target genes (Figure 5), we hypothesized that SDF1/ CXCR4 signaling may mediate the role of HIF1 $\alpha$ in ATII cell spreading during epithelial repair. Inhibition of SDF1/ CXCR4 signaling using the CXCR4 antagonist AMD3100 delayed repair of a scratch wound in primary ATII cells as well as MLE-12 cells (Figure 6A). Conversely, rSDF1 promoted cell spreading (Figure 6B) and actin polymerization at the leading wound edge (Figure 6C). CXCR4 is known to regulate cell motility by signaling through $\mathrm{Rac}^{47}$ and myosin IIA. ${ }^{48}$ Accordingly, inhibitors of myosin II and/or Rac1 also inhibited cell spreading (Figure 6, D and E). Incidentally, rVEGF had no effect on wound closure (data not shown).

\section{CXCR4/SDF1 Signaling Promotes the Resolution of Epithelial Permeability after Lung Injury}

To assess the potential relevance of SDF1/CXCR4 signaling during repair after lung injury in vivo, we first sought to determine whether those genes are up-regulated after LPS or $\mathrm{HCl}$. CXCR4 and SDF1 mRNA expression was increased in the whole lung homogenate at day 3 after lung injury in vivo 
A

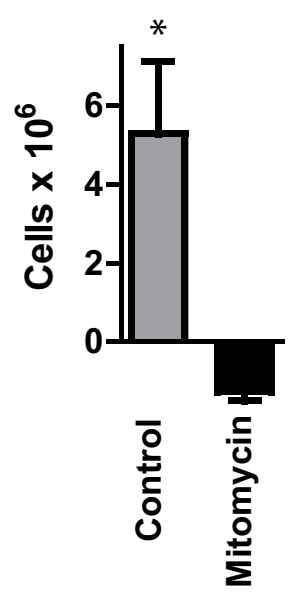

D

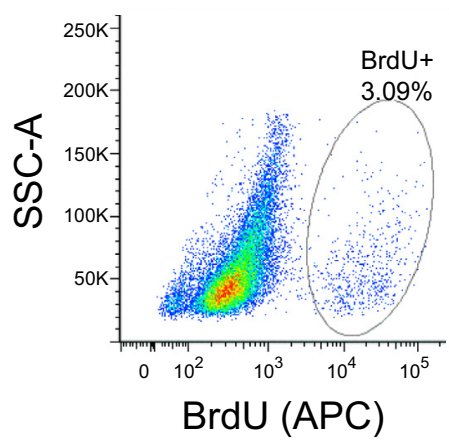

B
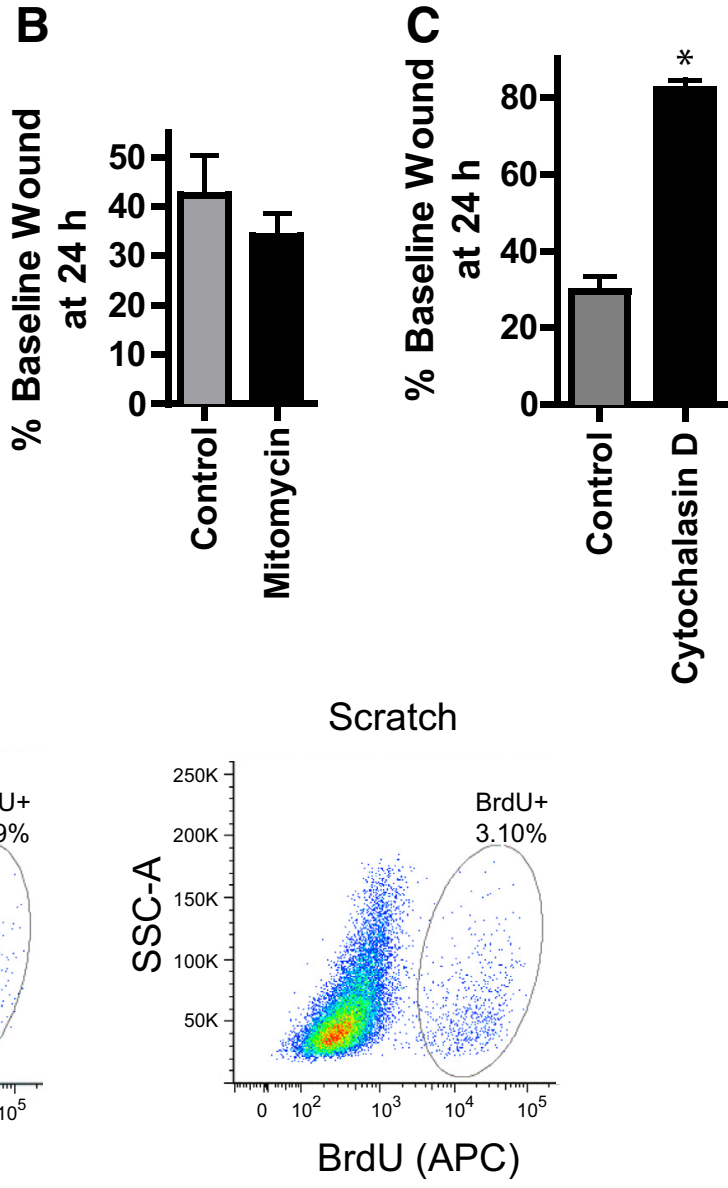

E

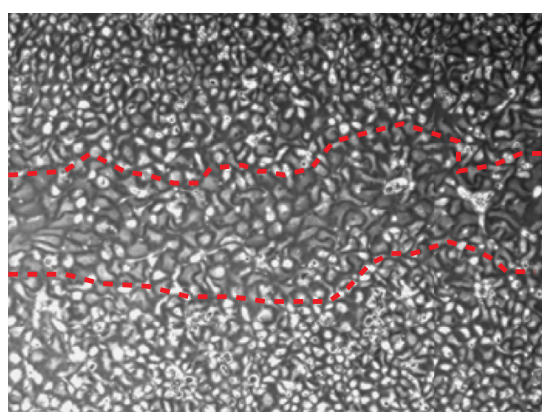

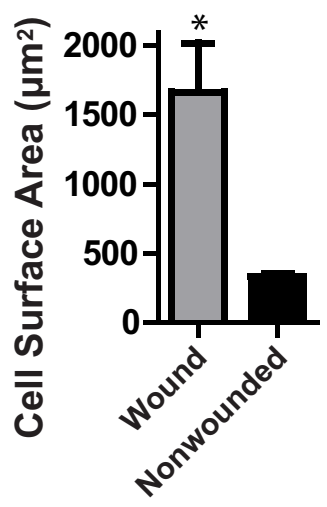

Figure 3 Scratch wounds repair via epithelial cell spreading. A: MLE-12 cells were grown to $30 \%$ confluence. Some wells were trypsinized and counted at $\mathrm{t}=0$; others were treated with $1 \mu \mathrm{g} /$ $\mathrm{mL}$ mitomycin. Cells were counted 24 hours later. The difference in cell number between $t=0$ and $t=24$ hours is shown. B and C: MLE-12 cells were subjected to scratch wounding, followed by treatment with $1 \mu \mathrm{g} / \mathrm{mL}$ mitomycin (B) or $0.1 \mu \mathrm{g} /$ $\mathrm{mL}$ cytochalasin $D(C)$. Images were acquired at $\mathrm{t}=0$ and 24 hours, and the percentage of initial wound width remaining was calculated. D: Rat ATII cells were subjected to scratch wounding and cultured in the presence of BrdU. At 24 hours, cells were trypsinized, stained with an anti-BrdU antibody, and analyzed by flow cytometry. E: Rat ATII cells were subjected to scratch wounding. At 48 hours, the surface area of cells within the wound (red dotted lines) or $>1 \mathrm{~mm}$ away from the wound was measured. Data are expressed as means \pm SEM $(\mathbf{A}-\mathbf{C}$ and $\mathbf{E}) .{ }^{*} P<0.05$. APC, allophycocyanin; ATII, alveolar type II; BrdU, bromodeoxyuridine; SSC, side scatter.
(Figure 7, A and B). SDF1 protein was also up-regulated after lung injury (Figure 7C and Supplemental Figure S9A). In addition, SDF1 was up-regulated in human ARDS lung tissue (Figure 7D). To determine whether SDF1/CXCR4 signaling may be involved in epithelial repair after lung injury, mice were treated with the CXCR4 antagonist AMD3100 daily, starting at day 3 after LPS, that is, after injury was established. CXCR4 blockade resulted in delayed resolution of permeability (Figure 7E) without any effect on inflammation (Supplemental Figure S9B). Of note, one mouse in the AMD3100 group died at day 5 after LPS, but no mice in the control group died.

\section{Discussion}

After ATI cell loss during lung injury, ATII cells reepithelialize the denuded basement membrane by proliferation and spreading. In this study, we have demonstrated that HIF signaling contributes to both critical steps of repair of the alveolar epithelium after lung injury. HIF signaling was shown to be activated in ATII cells during 
A

ShRNA NS HIF1a

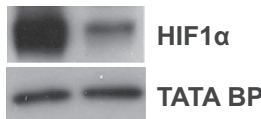

D
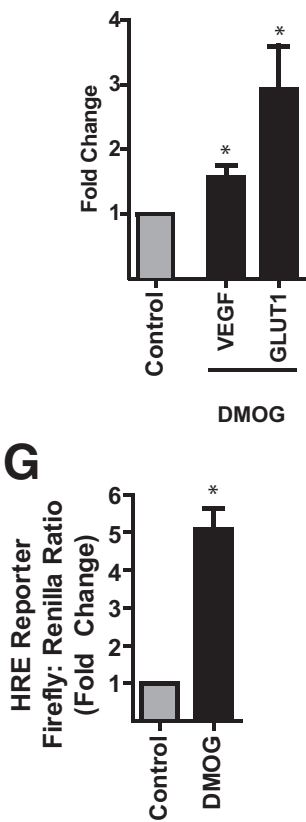

B

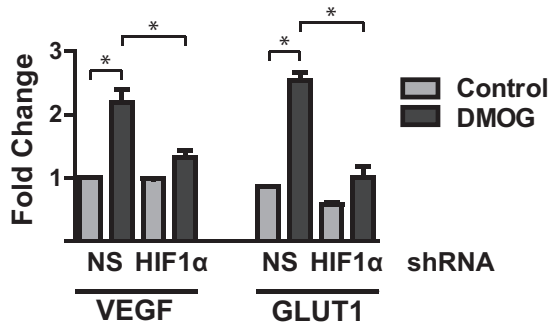

F
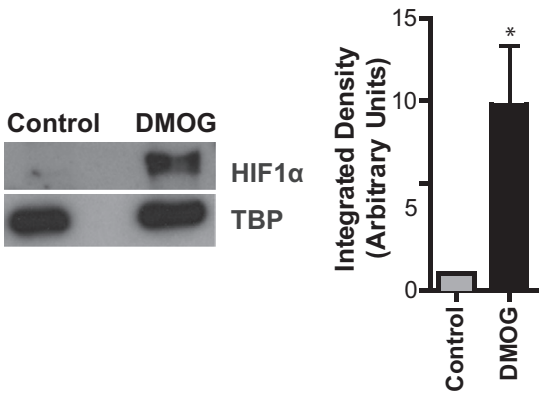

I

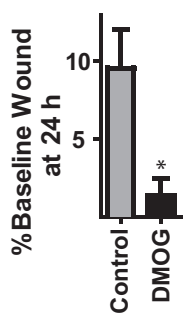

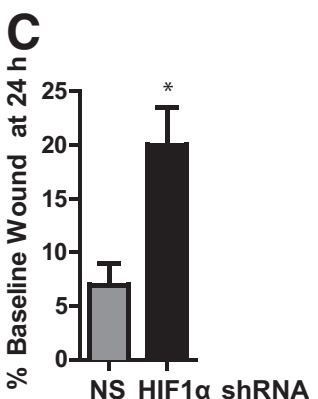

NS HIF1 $\alpha$ shRNA
H

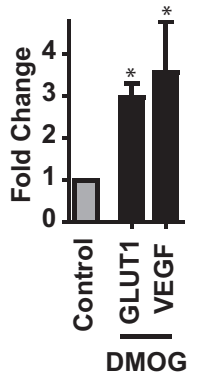

Figure 4 HIF promotes ATII cell spreading during epithelial repair. A-C: MLE-12 cells were transduced with a lentiviral construct expressing a NS or HIF1 $\alpha$ shRNA. A: Cells were exposed to $1 \%$ oxygen for 24 hours, followed by immunoblotting of nuclear extracts for HIF1 $\alpha$. B: Cells were stimulated with 1 mmol/L DMOG and GPCR was performed. C: Cells were grown to confluency and subjected to scratch wounding. The wound was imaged at $\mathrm{t}=0$ and 24 hours, and wound width was measured. D: Cultured rat ATII cells were stimulated with DMOG $1 \mathrm{mmol} / \mathrm{L}$ for 48 hours. RNA was harvested and qPCR was performed. E: Rat ATII cells were grown to confluence, subjected to scratch wounding, and cultured in the presence or absence of 0.5 to $1 \mathrm{mmol} / \mathrm{L}$ DMOG. F: MLE-12 cells cultured under normoxic conditions were treated with $1 \mathrm{mmol} / \mathrm{L}$ DMOG for 16 hours, followed by immunoblotting of nuclear extracts for HIF1 $\alpha$. G: MLE-12 cells were cotransfected with the HRE Firefly luciferase reporter plasmid and the Renilla luciferase reporter plasmid and treated with $1 \mathrm{mmol} / \mathrm{L}$ DMOG for 24 hours. Luciferase activity was determined. H: MLE-12 cells were treated with $1 \mathrm{mmol} / \mathrm{L}$ DMOG for 6 hours; qPCR was performed. I: MLE-12 cells were grown to confluence, subjected to scratch wounding, and cultured in the presence or absence of $1 \mathrm{mmol} / \mathrm{L}$ DMOG. Data are expressed as means \pm SEM (A-D and $\mathbf{F}-\mathbf{I})$. $n=6$ independent experiments (E). ${ }^{*} P<0.05$. ATII, alveolar type II; DMOG, dimethyloxalylglycine; GLUT1, glucose transporter 1 ; HIF, hypoxia-inducible factor; HRE, hypoxia response element; NS, nonsilencing; qPCR, real-time quantitative PCR; VEGF, vascular endothelial growth factor.

the repair phase after lung injury, and ATII cell-specific $H I F 1 \alpha$ KO mice exhibited a defect in ATII cell proliferation. The HIF target gene VEGF promoted ATII cell proliferation, both in cultured ATII cells as well as during repair after lung injury in vivo. HIF1 $\alpha$ also promoted ATII cell spreading. CXCR4 and its ligand SDF1 were found to be HIF target genes in ATII cells, were upregulated in lung injury, and promoted ATII cell spreading in vitro and the recovery of barrier function in vivo. By using state-of-the-art ATII cell-specific KO mice to dissect mechanisms of ATII cell proliferation, our study builds on previous work by us and others assessing mechanisms of ATII cell proliferation. ${ }^{49-52}$ In addition, we suggest the novel concept that a chemokine-receptor pathway, previously implicated in hematopoietic cell migration, ${ }^{26,27}$ is activated in structural cells, ATII epithelial cells, during lung injury and drives ATII cell spreading and the restoration of epithelial barrier integrity. In summary, our data suggest that after lung injury, HIF is activated in ATII cells and promotes ATII cell 


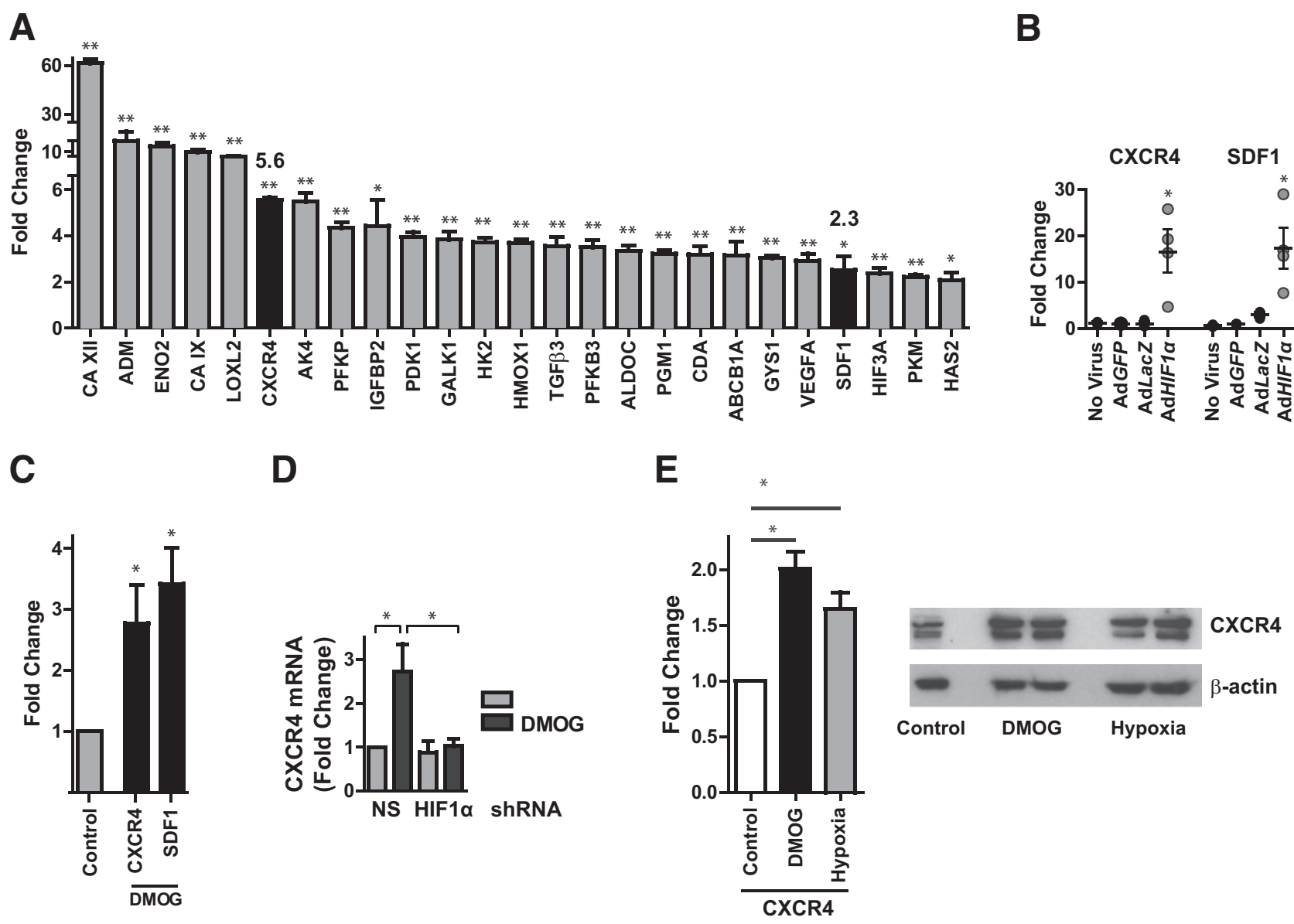

Figure $5 \quad$ CXCR4 and SDF1 are HIF target genes in ATII cells. A and B: Rat ATII cells were transduced with an adenovirus containing a constitutively active mutant HIF1 $\alpha$ construct (AdHIF1 $\alpha$ ) or GFP (AdGFP) or LacZ (AdLacZ). A genome-wide microarray (A) or qPCR (B) demonstrating mRNA expression of selected genes was performed. Fold-change of CXCR4 (5.6) and SDF1 (2.3) are indicated. C: Cultured rat ATII cells were treated with $1 \mathrm{mmol} / \mathrm{L}$ DMOG for 48 hours, RNA was harvested, and qPCR was performed. D: MLE-12 cells transduced with lentivirus expressing HIF1 $\alpha$ or NS shRNA were treated with 1 mmol/L DMOG for 6 hours, and qPCR was performed. E: MLE-12 cells were treated with DMOG $1 \mathrm{mmol} / \mathrm{L}$ or cultured in $1 \%$ oxygen for 16 hours, and qPCR or Western blot analysis for CXCR4 was performed. Data are expressed as means \pm SEM (A and C-E). ${ }^{*} P<0.05,{ }^{*} P<0.01$. ATII, alveolar type II; DMOG, dimethyloxalylglycine; HIF, hypoxia-inducible factor; NS, nonsilencing; qPCR, real-time quantitative PCR; SDF, stromal cell-derived factor.

proliferation by VEGF and ATII cell spreading via SDF1/ CXCR4 (Supplemental Figure S10).

The finding that HIF promotes ATII cell proliferation during repair after lung injury is consistent with the previously reported role of HIF in cell proliferation during tumorigenesis and angiogenesis. ${ }^{12,13}$ Although some literature has suggested a role for VEGF in alveolar epithelial cell proliferation, ${ }^{53}$ to our knowledge, our study is the first to demonstrate this effect in cultured primary ATII cells or during repair in an animal model of lung injury. Because HIF-dependent VEGF expression has been implicated in alveologenesis, ${ }^{20,21}$ this study substantiates the notion that developmental pathways may be reactivated to promote tissue repair after injury. Still, the mechanisms by which HIF1 $\alpha$ promotes ATII cell proliferation are likely multifactorial, possibly also involving up-regulation of other growth factors as well as glucose transporters and glycolytic enzymes that drive glycolysis, which in turn results in the synthesis of macromolecules (eg, nucleic acids, lipids, proteins) required for cell replication. ${ }^{54}$ Indeed, we observed up-regulation of several growth factors and glucose transporters/glycolytic enzymes by HIF1 $\alpha$ in ATII cells (Figure 5). Another intriguing possibility is that HIFdependent VEGF production by the alveolar epithelium triggers endothelial cell proliferation during repair after vascular injury as an example of endothelial-epithelial crosstalk during coordinated regeneration of multiple cell types in the alveolus.

Our results are also consistent with the role of HIF in cell motility during tumorigenesis ${ }^{13}$ as well as during wound repair in keratinocytes, ${ }^{14,15}$ a mechanism by which occlusive dressings induce local hypoxia to accelerate closure of surgical wounds. ${ }^{55}$ Moreover, HIF signaling has been implicated in barrier function at other mucosal surfaces. ${ }^{16,17,56}$ Our data support the notion that during lung injury, there is HIF-dependent up-regulation of both the chemokine SDF1 and its receptor CXCR4 and that SDF1/CXCR4 signaling promotes ATII cell spreading and 

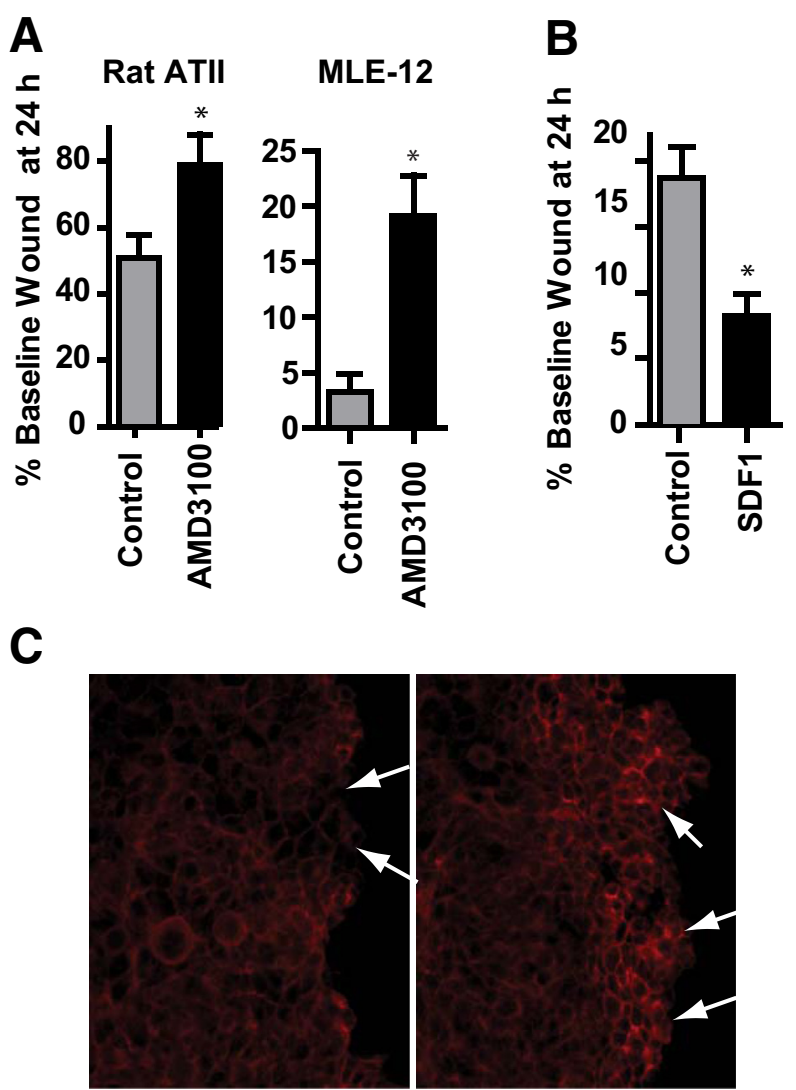

Control
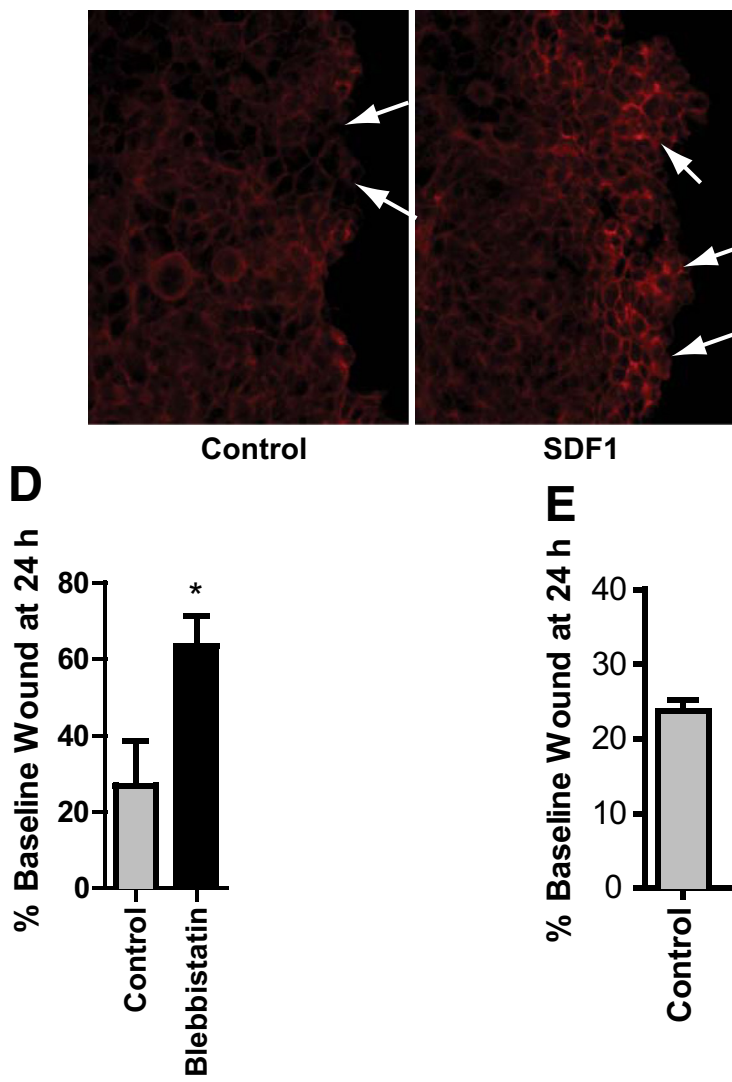

SDF1

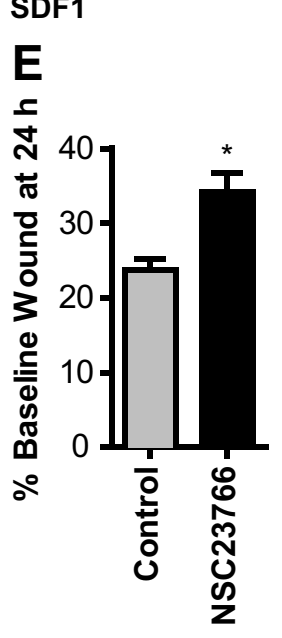

Figure 6 SDF1/CXCR4 signaling promotes ATII cell spreading. A-E: Rat ATII (A) or MLE-12 (A-E) cells were grown to confluence and subjected to scratch wounding. Immediately after the wound was made, $5 \mu \mathrm{g} / \mathrm{mL}$ AMD3100 (A), $500 \mathrm{ng} / \mathrm{mL}$ rSDF1 (B and C), $200 \mu \mathrm{mol} / \mathrm{L}$ blebbistatin (D), or $100 \mu \mathrm{mol} / \mathrm{L}$ NSC23766 (E) was added. A, B, D and E: Images were acquired, and the percentage of initial wound width remaining at 24 hours was calculated. C: Cells were fixed 5 minutes later and stained for phalloidin. Arrows indicate actin polymerization at leading wound edge. Data are expressed as means \pm SEM (A, B, D, and E). ${ }^{*} P<0.05$. ATII, alveolar type II; SDF, stromal cell-derived factor.

barrier restitution. The observed role for the SDF1/CXCR4 axis in cell spreading and barrier function is consistent with previous literature. ${ }^{29,57}$ Note that, although cell spreading, as measured by an increase in surface area covered by individual cells, contributes to wound closure in the scratch wound assay, we have not excluded the possibility that cell migration might also participate. Although previous reports have revealed SDF1/CXCR4 activation during lung injury, ${ }^{30,31}$ our study extends these findings by revealing a novel functional effect of this pathway. The effect of CXCR4 blockade on the resolution of permeability after lung injury, taken together with the direct role of SDF1/ CXCR4 in ATII cell spreading demonstrated in vitro, suggests that CXCR4 blockade might inhibit the restitution of barrier integrity by the inhibition of cell spreading. Although the CXCR4 inhibitor AMD3100 may also have effects on hematopoietic cells, we observed no difference in inflammatory cell influx. The expression of SDF1 in the lungs of ARDS patients underscores the relevance of this signaling pathway to the human disease. Although our results implicate HIF-dependent autocrine SDF1/CXCR4 signaling, we do not exclude the possibility of additional sources of SDF1, such as macrophages or platelets. ${ }^{58}$ Notably, in the immunostaining of mouse lung (Figure 7, $\mathrm{C}$ and D and Supplemental Figure S9A), SDF1 appears to line the alveolar septa, suggesting that it has been secreted. It is not possible to discern from these images what the cellular source of the SDF1 is, although ATII cells clearly produce SDF1 in vitro. In addition to its role in spreading, SDF1 may also promote alveolar regeneration by indirect mechanisms, such as inducing other cell types to produce epithelial growth factors. ${ }^{58}$ Finally, other HIF-dependent genes may contribute to cell spreading in other settings ${ }^{14,15,59,60}$; whether these pathways contribute to ATII cell spreading during repair after lung injury should be investigated.

Although severe, prolonged hypoxia and supraphysiologic activation of HIF can have deleterious effects, including alveolar epithelial apoptosis and lung injury, ${ }^{61-63}$ the alveolar epithelium tolerates moderate hypoxia well. ${ }^{61-64}$ We suggest that in inflammatory lung injury, physiologic activation of HIF signaling promotes repair, a notion that is consistent with its overall role in adaptation to hypoxic stress (eg, by angiogenesis, erythropoiesis, and glycolysis). In addition to dose-dependent effects, HIF may have pleiotropic effects depending on the specific target genes expressed. An intriguing possibility is that HIF induces expression of proapoptotic genes in susceptible cells while promoting repair in neighboring surviving cells by upregulation of different target genes (eg, VEGF, CXCR4, and SDF1).

Future studies should examine the mechanism by which HIF is activated in ATII cells during lung injury. Possibilities include hypoxic stabilization of HIF, perhaps because of focal oxygen consumption by inflammatory cells or microorganisms or decreased gas exchange because of airspace and interstitial edema, microvascular thrombosis, or atelectasis. In addition, various stimuli, including reactive oxygen/nitrogen species, ${ }^{65}$ LPS,${ }^{66}$ succinate, ${ }^{67}$ and growth factors and cytokines, ${ }^{68}$ can induce HIF 


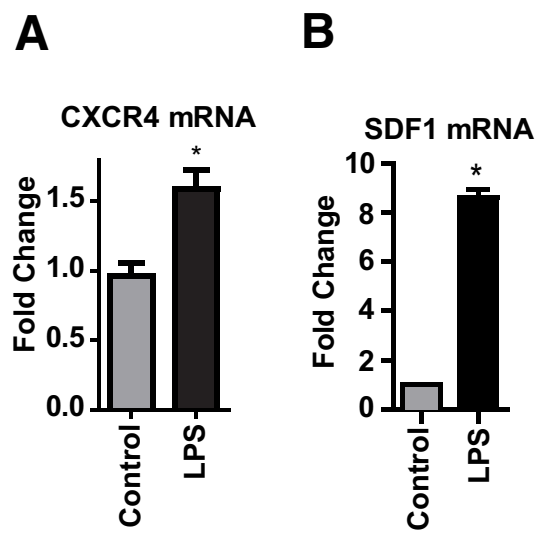

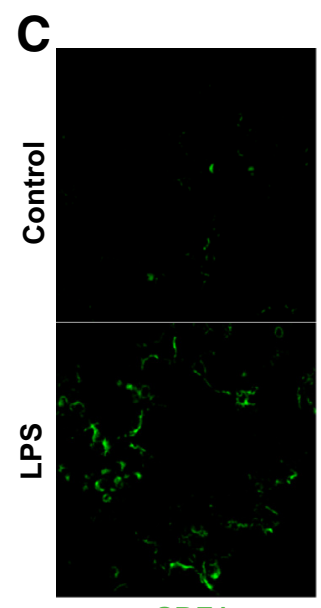

SDF1

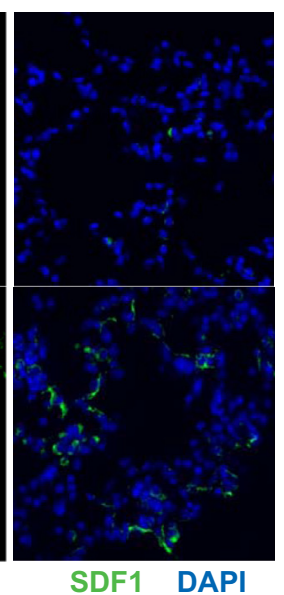

SDF1 DAPI

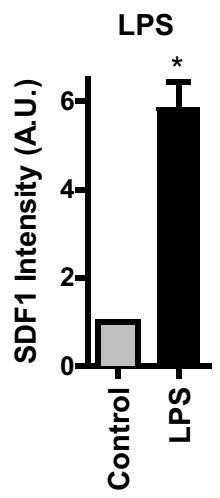

D

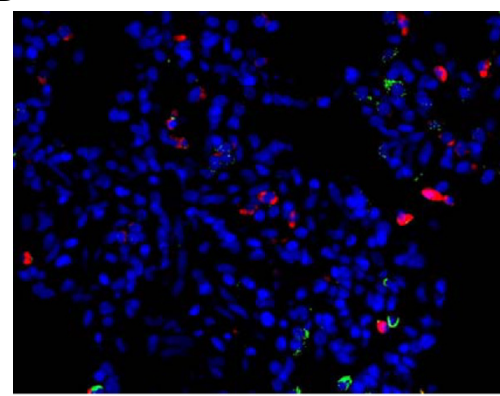

Normal

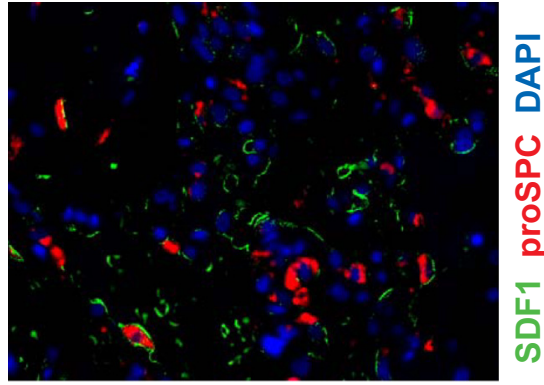

ARDS

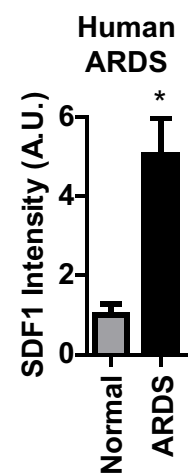

$\mathbf{E}$

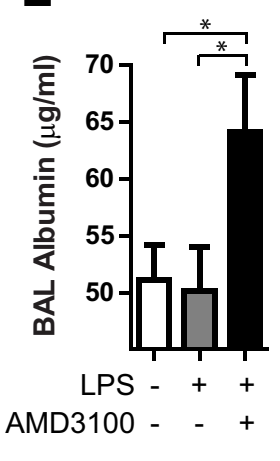

Figure 7 CXCR4 and SDF1 are up-regulated in animal models of lung injury and ARDS patients. A-C and E: Mice were treated with i.t. LPS. A and B: At day 3, RNA was harvested from the whole lung homogenate, and qPCR was performed. C: Lung sections were stained for SDF1. D: Lung sections from normal human lungs rejected for lung transplantation or autopsy specimens from ARDS patients were stained for SDF1 and proSPC. C and D: SDF1 intensity per HPF was quantified by ImageJ software version 1.48 (NIH, Bethesda, MD; http://imagej. nih.gov/ij). E: Beginning at day 3 after LPS, mice were administered AMD3100 i. p. daily and euthanized at day 7. BAL albumin was measured by ELISA. Data are expressed as means \pm SEM. $n \geq 5$ humans or mice per group. * $P<0.05$. ARDS, acute respiratory distress syndrome; BAL, bronchoalveolar lavage; ELISA, enzyme-linked immunosorbent assay; HPF, high power field; LPS, lipopolysaccharide; proSPC, prosurfactant protein C; qPCR, real-time quantitative PCR; SDF, stromal cell-derived factor.

stabilization or synthesis under normoxic conditions. Regardless of the mechanism driving HIF activation, it is likely that the surviving ATII cells located in the most injured areas, that is, the areas in most need of repair, are precisely those cells in which HIF is most highly activated. Interestingly, there is a small degree of active HIF signaling in the naive lung, including in ATII cells (Figure 1, B and C). The function of HIF1 in ATII cell homoeostasis remains to be determined, but maintenance of normal lung structure and barrier function does not appear to require HIF signaling (Supplemental Figure S4, B and C). We acknowledge that our conclusions are partially based on in vitro data that support but do not prove our hypothesis that this signaling cascade occurs in vivo.

ATII cell-specific KO of HIFl $\alpha$ partially attenuates ATII cell proliferation. Other pathways, which have been identified by us and others, also contribute to ATII cell proliferation. ${ }^{51,52,69-72}$ The mechanism by which these pathways may act cooperatively with HIF1 $\alpha$ to regulate repair should be the subject of future study. The observation that VEGF blockade more potently inhibits ATII cell proliferation than $H I F 1 \alpha \mathrm{KO}$ suggests that additional mechanisms may regulate VEGF. Future studies could also address the potential role of HIF2 $\alpha$, which regulates alveologenesis by VEGF ${ }^{21}$ in VEGF expression and ATII cell proliferation during repair after lung injury. Similarly, knockdown of HIF $1 \alpha$ only partially attenuates ATII cell spreading; other pathways are known to contribute. ${ }^{45,73-75}$ Finally, additional studies are warranted to determine which transcriptional cofactors might be required for HIF-dependent gene expression in ATII cells in the setting of lung injury. We speculate that $\beta$ catenin and p300, transcriptional cofactors that we have previously linked to ATII cell proliferation and spreading during repair, ${ }^{49,76}$ may bind to and enhance the transcriptional potency and specificity of HIF at the HRE, as has been demonstrated in other settings. ${ }^{77,78}$ 


\section{Conclusions}

We demonstrate here that HIF signaling promotes ATII cell proliferation and spreading, the two critical stages necessary to restore normal epithelial structure and function after lung injury. We speculate that an improved understanding of the molecular signals that promote ATII cell proliferation and spreading could ultimately be translated into novel therapeutic interventions to enhance lung repair in ARDS. The HIF pathway may be one target for such interventions.

\section{Acknowledgments}

We thank S. Courtney Frasch, William Janssen, Donna Bratton, Stijn de Langhe, Sonia Leach, and Karen Edeen for technical assistance and Irina Petrache, Peter Henson, and Brian Graham for thoughtful discussions.

\section{Supplemental Data}

Supplemental material for this article can be found at http://dx.doi.org/10.1016/j.ajpath.2017.04.012.

\section{References}

1. ARDS Definition Task Force, Ranieri VM, Rubenfeld GD, Thompson BT, Ferguson ND, Caldwell E, Fan E, Camporota L, Slutsky AS: Acute respiratory distress syndrome: the Berlin Definition. JAMA 2012, 307:2526-2533

2. Matthay MA, Ware LB, Zimmerman GA: The acute respiratory distress syndrome. J Clin Invest 2012, 122:2731-2740

3. Wiener-Kronish JP, Albertine KH, Matthay MA: Differential responses of the endothelial and epithelial barriers of the lung in sheep to Escherichia coli endotoxin. J Clin Invest 1991, 88:864-875

4. Montaner JS, Tsang J, Evans KG, Mullen JB, Burns AR, Walker DC, Wiggs B, Hogg JC: Alveolar epithelial damage. A critical difference between high pressure and oleic acid-induced low pressure pulmonary edema. J Clin Invest 1986, 77:1786-1796

5. Matthay MA, Wiener-Kronish JP: Intact epithelial barrier function is critical for the resolution of alveolar edema in humans. Am Rev Respir Dis 1990, 142:1250-1257

6. Ware LB, Matthay MA: Alveolar fluid clearance is impaired in the majority of patients with acute lung injury and the acute respiratory distress syndrome. Am J Respir Crit Care Med 2001, 163:1376-1383

7. Evans MJ, Cabral LJ, Stephens RJ, Freeman G: Renewal of alveolar epithelium in the rat following exposure to NO2. Am J Pathol 1973, 70:175-198

8. Adamson IY, Bowden DH: The type 2 cell as progenitor of alveolar epithelial regeneration. A cytodynamic study in mice after exposure to oxygen. Lab Invest 1974, 30:35-42

9. Desai TJ, Brownfield DG, Krasnow MA: Alveolar progenitor and stem cells in lung development, renewal and cancer. Nature 2014, 507:190-194

10. Barkauskas CE, Cronce MJ, Rackley CR, Bowie EJ, Keene DR, Stripp BR, Randell SH, Noble PW, Hogan BL: Type 2 alveolar cells are stem cells in adult lung. J Clin Invest 2013, 123:3025-3036

11. Eltzschig HK, Carmeliet P: Hypoxia and inflammation. N Engl J Med 2011, 364:656-665

12. Semenza GL: Targeting HIF-1 for cancer therapy. Nat Rev Cancer 2003, 3:721-732

13. Carmeliet P, Dor Y, Herbert JM, Fukumura D, Brusselmans K, Dewerchin M, Neeman M, Bono F, Abramovitch R, Maxwell P,
Koch CJ, Ratcliffe P, Moons L, Jain RK, Collen D, Keshert E: Role of HIF-1alpha in hypoxia-mediated apoptosis, cell proliferation and tumour angiogenesis. Nature 1998, 394:485-490

14. Elson DA, Ryan HE, Snow JW, Johnson R, Arbeit JM: Coordinate up-regulation of hypoxia inducible factor (HIF)-1alpha and HIF-1 target genes during multi-stage epidermal carcinogenesis and wound healing. Cancer Res 2000, 60:6189-6195

15. Fitsialos G, Bourget I, Augier S, Ginouves A, Rezzonico R, Odorisio T, Cianfarani F, Virolle T, Pouyssegur J, Meneguzzi G, Berra E, Ponzio G, Busca R: HIF1 transcription factor regulates laminin-332 expression and keratinocyte migration. J Cell Sci 2008, 121:2992-3001

16. Synnestvedt K, Furuta GT, Comerford KM, Louis N, Karhausen J, Eltzschig HK, Hansen KR, Thompson LF, Colgan SP: Ecto-5'nucleotidase (CD73) regulation by hypoxia-inducible factor-1 mediates permeability changes in intestinal epithelia. J Clin Invest 2002, 110:993-1002

17. Furuta GT, Turner JR, Taylor CT, Hershberg RM, Comerford K, Narravula S, Podolsky DK, Colgan SP: Hypoxia-inducible factor 1-dependent induction of intestinal trefoil factor protects barrier function during hypoxia. J Exp Med 2001, 193:1027-1034

18. Rey S, Lee K, Wang CJ, Gupta K, Chen S, McMillan A, Bhise N, Levchenko A, Semenza GL: Synergistic effect of HIF-1alpha gene therapy and HIF-1-activated bone marrow-derived angiogenic cells in a mouse model of limb ischemia. Proc Natl Acad Sci U S A 2009, 106:20399-20404

19. Eckle T, Kohler D, Lehmann R, El Kasmi K, Eltzschig HK: Hypoxiainducible factor- 1 is central to cardioprotection: a new paradigm for ischemic preconditioning. Circulation 2008, 118:166-175

20. Saini Y, Harkema JR, LaPres JJ: HIF1alpha is essential for normal intrauterine differentiation of alveolar epithelium and surfactant production in the newborn lung of mice. J Biol Chem 2008, 283: 33650-33657

21. Compernolle V, Brusselmans K, Acker T, Hoet P, Tjwa M, Beck H, Plaisance S, Dor Y, Keshet E, Lupu F, Nemery B, Dewerchin M, Van Veldhoven P, Plate K, Moons L, Collen D, Carmeliet P: Loss of HIF-2alpha and inhibition of VEGF impair fetal lung maturation, whereas treatment with VEGF prevents fatal respiratory distress in premature mice. Nat Med 2002, 8:702-710

22. Eckle T, Brodsky K, Bonney M, Packard T, Han J, Borchers CH, Mariani TJ, Kominsky DJ, Mittelbronn M, Eltzschig HK: HIF1A reduces acute lung injury by optimizing carbohydrate metabolism in the alveolar epithelium. PLoS Biol 2013, 11:e1001665

23. Tibboel J, Groenman FA, Selvaratnam J, Wang J, Tseu I, Huang Z, Caniggia I, Luo D, van Tuyl M, Ackerley C, de Jongste JC, Tibboel D, Post M: Hypoxia-inducible factor- 1 stimulates postnatal lung development but does not prevent $\mathrm{O} 2$-induced alveolar injury. Am J Respir Cell Mol Biol 2015, 52:448-458

24. Weng T, Poth JM, Karmouty-Quintana H, Garcia-Morales LJ, Melicoff E, Luo F, Chen NY, Evans CM, Bunge RR, Bruckner BA, Loebe M, Volcik KA, Eltzschig HK, Blackburn MR: Hypoxiainduced deoxycytidine kinase contributes to epithelial proliferation in pulmonary fibrosis. Am J Respir Crit Care Med 2014, 190: $1402-1412$

25. Carmeliet P, Ferreira V, Breier G, Pollefeyt S, Kieckens L, Gertsenstein M, Fahrig M, Vandenhoeck A, Harpal K, Eberhardt C, Declercq C, Pawling J, Moons L, Collen D, Risau W, Nagy A: Abnormal blood vessel development and lethality in embryos lacking a single VEGF allele. Nature 1996, 380:435-439

26. Bleul CC, Fuhlbrigge RC, Casasnovas JM, Aiuti A, Springer TA: A highly efficacious lymphocyte chemoattractant, stromal cell-derived factor 1 (SDF-1). J Exp Med 1996, 184:1101-1109

27. Aiuti A, Webb IJ, Bleul C, Springer T, Gutierrez-Ramos JC: The chemokine SDF-1 is a chemoattractant for human CD34+ hematopoietic progenitor cells and provides a new mechanism to explain the mobilization of CD34+ progenitors to peripheral blood. J Exp Med 1997, 185:111-120 
28. Muller A, Homey B, Soto H, Ge N, Catron D, Buchanan ME, McClanahan T, Murphy E, Yuan W, Wagner SN, Barrera JL, Mohar A, Verastegui E, Zlotnik A: Involvement of chemokine receptors in breast cancer metastasis. Nature 2001, 410:50-56

29. Smith JM, Johanesen PA, Wendt MK, Binion DG, Dwinell MB: CXCL12 activation of CXCR4 regulates mucosal host defense through stimulation of epithelial cell migration and promotion of intestinal barrier integrity. Am J Physiol Gastrointest Liver Physiol 2005, 288:G316-G326

30. Phillips RJ, Burdick MD, Hong K, Lutz MA, Murray LA, Xue YY, Belperio JA, Keane MP, Strieter RM: Circulating fibrocytes traffic to the lungs in response to CXCL12 and mediate fibrosis. J Clin Invest 2004, 114:438-446

31. Petty JM, Sueblinvong V, Lenox CC, Jones CC, Cosgrove GP, Cool CD, Rai PR, Brown KK, Weiss DJ, Poynter ME, Suratt BT: Pulmonary stromal-derived factor-1 expression and effect on neutrophil recruitment during acute lung injury. J Immunol 2007, 178:8148-8157

32. Schioppa T, Uranchimeg B, Saccani A, Biswas SK, Doni A, Rapisarda A, Bernasconi S, Saccani S, Nebuloni M, Vago L, Mantovani A, Melillo G, Sica A: Regulation of the chemokine receptor CXCR4 by hypoxia. J Exp Med 2003, 198:1391-1402

33. Ceradini DJ, Kulkarni AR, Callaghan MJ, Tepper OM, Bastidas N, Kleinman ME, Capla JM, Galiano RD, Levine JP, Gurtner GC: Progenitor cell trafficking is regulated by hypoxic gradients through HIF-1 induction of SDF-1. Nat Med 2004, 10: $858-864$

34. Chapman HA, Li X, Alexander JP, Brumwell A, Lorizio W, Tan K, Sonnenberg A, Wei Y, Vu TH: Integrin alpha6beta4 identifies an adult distal lung epithelial population with regenerative potential in mice. J Clin Invest 2011, 121:2855-2862

35. Messier EM, Mason RJ, Kosmider B: Efficient and rapid isolation and purification of mouse alveolar type II epithelial cells. Exp Lung Res 2012, 38:363-373

36. Lagache T, Sauvonnet N, Danglot L, Olivo-Marin JC: Statistical analysis of molecule colocalization in bioimaging. Cytometry A 2015, 87:568-579

37. Dobbs LG, Mason RJ: Pulmonary alveolar type II cells isolated from rats. Release of phosphatidylcholine in response to beta-adrenergic stimulation. J Clin Invest 1979, 63:378-387

38. Sheta EA, Trout H, Gildea JJ, Harding MA, Theodorescu D: Cell density mediated pericellular hypoxia leads to induction of HIF1alpha via nitric oxide and Ras/MAP kinase mediated signaling pathways. Oncogene 2001, 20:7624-7634

39. Ahmad A, Ahmad S, Glover L, Miller SM, Shannon JM, Guo X, Franklin WA, Bridges JP, Schaack JB, Colgan SP, White CW: Adenosine A2A receptor is a unique angiogenic target of HIF-2alpha in pulmonary endothelial cells. Proc Natl Acad Sci U S A 2009, 106: 10684-10689

40. Livak KJ, Schmittgen TD: Analysis of relative gene expression data using real-time quantitative PCR and the 2(-Delta C(T)) Method. Methods 2001, 25:402-408

41. McElroy MC, Pittet JF, Allen L, Wiener-Kronish JP, Dobbs LG: Biochemical detection of type I cell damage after nitrogen dioxide-induced lung injury in rats. Am J Physiol 1997, 273: L1228-L1234

42. Safran M, Kim WY, O'Connell F, Flippin L, Gunzler V, Horner JW, Depinho RA, Kaelin WG Jr: Mouse model for noninvasive imaging of HIF prolyl hydroxylase activity: assessment of an oral agent that stimulates erythropoietin production. Proc Natl Acad Sci U S A 2006, 103:105-110

43. Hu CJ, Wang LY, Chodosh LA, Keith B, Simon MC: Differential roles of hypoxia-inducible factor 1alpha (HIF-1alpha) and HIF2alpha in hypoxic gene regulation. Mol Cell Biol 2003, 23: 9361-9374

44. Desai LP, Chapman KE, Waters CM: Mechanical stretch decreases migration of alveolar epithelial cells through mechanisms involving
Rac1 and Tiam1. Am J Physiol Lung Cell Mol Physiol 2008, 295: L958-L965

45. Atabai K, Ishigaki M, Geiser T, Ueki I, Matthay MA, Ware LB: Keratinocyte growth factor can enhance alveolar epithelial repair by nonmitogenic mechanisms. Am J Physiol Lung Cell Mol Physiol 2002, 283:L163-L169

46. Wikenheiser KA, Vorbroker DK, Rice WR, Clark JC, Bachurski CJ, Oie HK, Whitsett JA: Production of immortalized distal respiratory epithelial cell lines from surfactant protein $\mathrm{C} /$ simian virus 40 large tumor antigen transgenic mice. Proc Natl Acad Sci U S A 1993, 90: 11029-11033

47. Nishita M, Aizawa H, Mizuno K: Stromal cell-derived factor 1alpha activates LIM kinase 1 and induces cofilin phosphorylation for T-cell chemotaxis. Mol Cell Biol 2002, 22:774-783

48. Rey M, Vicente-Manzanares M, Viedma F, Yanez-Mo M, Urzainqui A, Barreiro O, Vazquez J, Sanchez-Madrid F: Cutting edge: association of the motor protein nonmuscle myosin heavy chain-IIA with the $\mathrm{C}$ terminus of the chemokine receptor CXCR4 in T lymphocytes. J Immunol 2002, 169:5410-5414

49. Zemans RL, Briones N, Campbell M, McClendon J, Young SK, Suzuki T, Yang IV, De Langhe S, Reynolds SD, Mason RJ, Kahn M, Henson PM, Colgan SP, Downey GP: Neutrophil transmigration triggers repair of the lung epithelium via beta-catenin signaling. Proc Natl Acad Sci U S A 2011, 108:15990-15995

50. Tanjore H, Degryse AL, Crossno PF, Xu XC, McConaha ME, Jones BR, Polosukhin VV, Bryant AJ, Cheng DS, Newcomb DC, McMahon FB, Gleaves LA, Blackwell TS, Lawson WE: beta-catenin in the alveolar epithelium protects from lung fibrosis following intratracheal bleomycin. Am J Respir Crit Care Med 2013, 187: 630-639

51. Liu Y, Sadikot RT, Adami GR, Kalinichenko VV, Pendyala S, Natarajan V, Zhao YY, Malik AB: FoxM1 mediates the progenitor function of type II epithelial cells in repairing alveolar injury induced by Pseudomonas aeruginosa. J Exp Med 2011, 208:1473-1484

52. Fehrenbach H, Kasper M, Tschernig $T$, Pan $T$, Schuh D, Shannon JM, Müller M, Mason RJ: Keratinocyte growth factorinduced hyperplasia of rat alveolar type II cells in vivo is resolved by differentiation into type I cells and by apoptosis. Eur Respir J 1999, 14:534-544

53. Ohwada A, Yoshioka Y, Iwabuchi K, Nagaoka I, Dambara T, Fukuchi Y: VEGF regulates the proliferation of acid-exposed alveolar lining epithelial cells. Thorax 2003, 58:328-332

54. López-Lázaro M: The warburg effect: why and how do cancer cells activate glycolysis in the presence of oxygen? Anticancer Agents Med Chem 2008, 8:305-312

55. Winter GD: Effect of air exposure and occlusion on experimental human skin wounds. Nature 1963, 200:378-379

56. Olson N, Hristova M, Heintz NH, Lounsbury KM, van der Vliet A: Activation of hypoxia-inducible factor- 1 protects airway epithelium against oxidant-induced barrier dysfunction. Am J Physiol Lung Cell Mol Physiol 2011, 301:L993-L1002

57. Ghosh MC, Makena PS, Gorantla V, Sinclair SE, Waters CM: CXCR4 regulates migration of lung alveolar epithelial cells through activation of Rac1 and matrix metalloproteinase-2. Am J Physiol Lung Cell Mol Physiol 2012, 302:L846-L856

58. Rafii S, Cao Z, Lis R, Siempos II, Chavez D, Shido K, Rabbany SY, Ding BS: Platelet-derived SDF-1 primes the pulmonary capillary vascular niche to drive lung alveolar regeneration. Nat Cell Biol 2015, 17:123-136

59. Daniel RJ, Groves RW: Increased migration of murine keratinocytes under hypoxia is mediated by induction of urokinase plasminogen activator. J Invest Dermatol 2002, 119:1304-1309

60. Li W, Li Y, Guan S, Fan J, Cheng CF, Bright AM, Chinn C, Chen M, Woodley DT: Extracellular heat shock protein-90alpha: linking hypoxia to skin cell motility and wound healing. EMBO J 2007, 26:1221-1233

61. Santore MT, McClintock DS, Lee VY, Budinger GR, Chandel NS: Anoxia-induced apoptosis occurs through a mitochondria-dependent 
pathway in lung epithelial cells. Am J Physiol Lung Cell Mol Physiol 2002, 282:L727-L734

62. Krick S, Eul BG, Hanze J, Savai R, Grimminger F, Seeger W, Rose F: Role of hypoxia-inducible factor-1alpha in hypoxia-induced apoptosis of primary alveolar epithelial type II cells. Am J Respir Cell Mol Biol 2005, 32:395-403

63. Jain M, Sznajder JI: Effects of hypoxia on the alveolar epithelium. Proc Am Thorac Soc 2005, 2:202-205

64. Fisher AB, Hyde RW, Reif JS: Insensitivity of the alveolar septum to local hypoxia. Am J Physiol 1972, 223:770-776

65. Chandel NS, Maltepe E, Goldwasser E, Mathieu CE, Simon MC, Schumacker PT: Mitochondrial reactive oxygen species trigger hypoxiainduced transcription. Proc Natl Acad Sci U S A 1998, 95:11715-11720

66. Blouin CC, Page EL, Soucy GM, Richard DE: Hypoxic gene activation by lipopolysaccharide in macrophages: implication of hypoxiainducible factor 1alpha. Blood 2004, 103:1124-1130

67. Tannahill GM, Curtis AM, Adamik J, Palsson-McDermott EM, McGettrick AF, Goel G, Frezza C, Bernard NJ, Kelly B, Foley NH, Zheng L, Gardet A, Tong Z, Jany SS, Corr SC, Haneklaus M, Caffrey BE, Pierce K, Walmsley S, Beasley FC, Cummins E, Nizet V, Whyte M, Taylor CT, Lin H, Masters SL, Gottlieb E, Kelly VP, Clish C, Auron PE, Xavier RJ, O'Neill LA: Succinate is an inflammatory signal that induces IL-1 beta through HIF-1alpha. Nature 2013, 496:238-242

68. Wenger RH, Stiehl DP, Camenisch G: Integration of oxygen signaling at the consensus HRE. Sci STKE 2005, 2005:re12

69. Yano T, Mason RJ, Pan T, Deterding RR, Nielsen LD, Shannon JM: KGF regulates pulmonary epithelial proliferation and surfactant protein gene expression in adult rat lung. Am J Physiol Lung Cell Mol Physiol 2000, 279:L1146-L1158

70. Mason RJ, Leslie CC, McCormick-Shannon K, Deterding RR, Nakamura T, Rubin JS, Shannon JM: Hepatocyte growth factor is a growth factor for rat alveolar type II cells. Am J Respir Cell Mol Biol 1994, 11:561-567
71. Panos RJ, Rubin JS, Csaky KG, Aaronson SA, Mason RJ: Keratinocyte growth factor and hepatocyte growth factor/scatter factor are heparin-binding growth factors for alveolar type II cells in fibroblastconditioned medium. J Clin Invest 1993, 92:969-977

72. Cakarova L, Marsh LM, Wilhelm J, Mayer K, Grimminger F, Seeger W, Lohmeyer J, Herold S: Macrophage tumor necrosis factor-alpha induces epithelial expression of granulocyte-macrophage colony-stimulating factor: impact on alveolar epithelial repair. Am J Respir Crit Care Med 2009, 180:521-532

73. Kheradmand F, Folkesson HG, Shum L, Derynk R, Pytela R, Matthay MA: Transforming growth factor-alpha enhances alveolar epithelial cell repair in a new in vitro model. Am J Physiol 1994, 267: L728-L738

74. Pittet JF, Koh H, Fang X, Iles K, Christiaans S, Anjun N, Wagener BM, Park DW, Zmijewski JW, Matthay MA, Roux J; HMGB1 accelerates alveolar epithelial repair via an IL-1beta- and alphavbeta6 integrin-dependent activation of TGF-beta1. PLoS One 2013, 8:e63907

75. Geiser T, Jarreau PH, Atabai K, Matthay MA: Interleukin-1beta augments in vitro alveolar epithelial repair. Am J Physiol Lung Cell Mol Physiol 2000, 279:L1184-L1190

76. Zemans RL, McClendon J, Aschner Y, Briones N, Young SK, Lau LF, Kahn M, Downey GP: Role of beta-catenin-regulated CCN matricellular proteins in epithelial repair after inflammatory lung injury. Am J Physiol Lung Cell Mol Physiol 2013, 304:L415-L427

77. Kaidi A, Williams AC, Paraskeva C: Interaction between beta-catenin and HIF-1 promotes cellular adaptation to hypoxia. Nat Cell Biol 2007, 9:210-217

78. Xi Y, Wei Y, Sennino B, Ulsamer A, Kwan I, Brumwell AN, Tan K, Aghi MK, McDonald DM, Jablons DM, Chapman HA: Identification of pY654-beta-catenin as a critical co-factor in hypoxia-inducible factor-1alpha signaling and tumor responses to hypoxia. Oncogene 2013, 32:5048-5057 